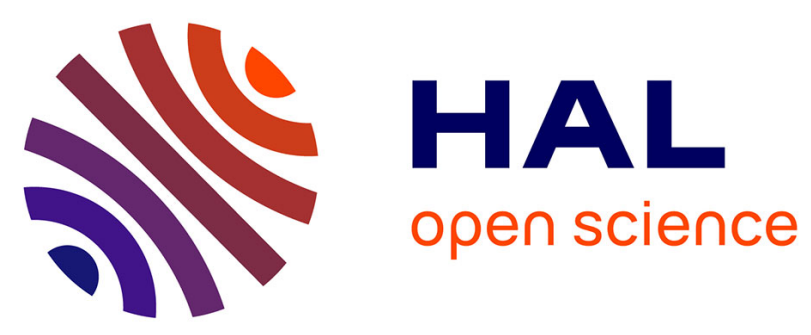

\title{
Synthesis and polymerization of cyclobutenyl-functionalized polylactide and polycaprolactone: a consecutive ROP/ROMP route towards poly(1,4-butadiene)-g-polyesters
}

Flavien Leroux, V. Montembault, Sagrario Pascual, William Guerin, Sophie M. Guillaume, Laurent Fontaine

\section{To cite this version:}

Flavien Leroux, V. Montembault, Sagrario Pascual, William Guerin, Sophie M. Guillaume, et al.. Synthesis and polymerization of cyclobutenyl-functionalized polylactide and polycaprolactone: a consecutive ROP/ROMP route towards poly(1,4-butadiene)-g-polyesters. Journal of Polymer Science Part A: Polymer Chemistry, 2014, 5 (10), pp.3476-3486. 10.1039/C3PY01611K . hal-01066277

\section{HAL Id: hal-01066277 https://hal.science/hal-01066277}

Submitted on 22 Sep 2014

HAL is a multi-disciplinary open access archive for the deposit and dissemination of scientific research documents, whether they are published or not. The documents may come from teaching and research institutions in France or abroad, or from public or private research centers.
L'archive ouverte pluridisciplinaire HAL, est destinée au dépôt et à la diffusion de documents scientifiques de niveau recherche, publiés ou non, émanant des établissements d'enseignement et de recherche français ou étrangers, des laboratoires publics ou privés. 


\title{
Synthesis and Polymerization of Cyclobutenyl-Functionalized Polylactide and Polycaprolactone: A Consecutive ROP/ROMP Route to Poly(1,4-butadiene)-g-Polyesters
}

\author{
Flavien Leroux,${ }^{a}$ Véronique Montembault, ${ }^{a}$ Sagrario Pascual, ${ }^{a}$ William Guérin, ${ }^{b}$ Sophie M. \\ Guillaume, ${ }^{b}$ and Laurent Fontaine ${ }^{* a}$
}

${ }^{a}$ Institut des Molécules et Matériaux du Mans (IMMM), Equipe Méthodologie et Synthèse des Polymères, UMR CNRS 6283, Université du Maine, Avenue Olivier Messiaen, 72085 Le Mans Cedex 9, France. Fax: +33 (0)2 4383 37 54; Tel: +33 (0)2 438333 30 ; E-Mail : laurent.fontaine@ univlemans.fr

${ }^{\mathrm{b}}$ Institut des Sciences Chimiques de Rennes, Organometallics, Materials and Catalysis, UMR 6226 CNRS, Université de Rennes 1, Campus de

Beaulieu, 35042 Rennes Cedex, France.

Efficient preparation of cyclobutenyl end-functionalized polyester macromonomers bearing polylactide (PLA) or poly( $\varepsilon$-caprolactone) (PCL) arms was achieved by organocatalyzed ringopening polymerization (ROP) of $L$-lactide or $\varepsilon$-caprolactone in the presence of $c i s-3,4-$ bis(hydroxymethyl)cyclobutene or cis-4-benzyloxymethyl-3-hydroxymethylcyclobutene acting as initiator. Cyclobutenyl end-functionalized PLA and PCL macromonomers having one or two arms were obtained in high yields with excellent control over molecular weights (up to $11000 \mathrm{~g}^{\mathrm{mol}} \mathrm{m}^{-1}$ ) and dispersity (PDI < 1.25) by organocatalyzed ROP using 4-( $N, N$-dimethylamino)pyridine (DMAP) and 1,5,7-triazabicyclo[4.4.0]dec-5-ene (TBD), respectively. Ring-opening metathesis polymerization (ROMP) of the macromonomers using ruthenium-based Grubbs' second generation catalyst afforded well-defined polybutadiene- $g$-polyester copolymers having an exclusively linear polybutadiene backbone with a strictly 1,4-type microstructure, with molecular weights ranging from 20000 to 170 000 g. $\mathrm{mol}^{-1}$ and low dispersity (PDI $\leq 1.30$ ). The products resulting from this consecutive ROP/ROMP route represent the first examples of poly(1,4-butadiene)-g-polyesters through the macromonomer route.

\section{Introduction}

Ring-opening metathesis polymerization (ROMP) has emerged as a powerful tool to prepare graft copolymers (also denoted as bottlebrush copolymers) using the three well-known strategies: grafting-from, grafting-onto, and grafting-through routes. ${ }^{1}$ The most often used method, namely the grafting-through (or macromonomer) route, relies on the ROMP of well-defined polymers bearing a "ROMP-able" strained ring such as norbornene ${ }^{2}$ or oxanorbornene. ${ }^{3}$ In our group, we have developed a number of efficient synthetic strategies based on the cyclobutene ring as the "ROMP-able" functionality to prepare well-defined graft copolymers having a strictly 1,4-polybutadiene main chain with a high density of grafts. ${ }^{4-7}$ Cyclobutene derivatives have been much less investigated in ROMP compared to their (oxa)norbornene counterparts, ${ }^{4 a, 8}$ although this approach provides final polymers having an exclusively linear polybutadiene backbone with a strictly 1,4-type microstructure that is not easily attainable by other (ionic or radical) polymerization processes. We have previously demonstrated that the cyclobutenyl double bond survives various reversible deactivation radical polymerization processes such as atom transfer radical polymerization (ATRP), ${ }^{5}$ reversible addition-fragmentation transfer (RAFT) polymerization, ${ }^{6}$ and click copper-catalyzed azide-alkyne cycloaddition (CuAAC). ${ }^{6,7}$

Driven by our interest in developing new efficient methodologies to prepare well-defined grafted poly(1,4-butadiene)s, we used in the present work a consecutive ring-opening polymerization (ROP)/ROMP route to prepare poly(1,4-butadiene)-g-polyesters from cyclobutenyl macromonomers bearing one or two polyester segment(s) derived from $L$-lactide (LA) or $\varepsilon$-caprolactone (CL).

Polylactide (PLA) and poly( $\varepsilon$-caprolactone) (PCL) are important polymers as they are easily (bio)degradable and have tremendous applications as engineering plastics and within the biomedical field. ${ }^{9}$ An attractive feature of polyester-grafted copolymers is their potential to act as building blocks for nanomaterials synthesis thanks to the hydrolytically degradable polyester grafts. ${ }^{2 b}$ Previously reported works devoted to the synthesis of polycycloalkene- $g$-polyesters by the grafting-through method have focused on the ROMP of (oxa)norbornenyl-functionalized PLA ${ }^{2 \mathrm{~b}, 2 \mathrm{~d}, 3 \mathrm{a}, 10}$ and PCL $^{2 \mathrm{~h}, 11}$ macromonomers using ruthenium-based catalysts. In the present study, we investigated the synthesis and ROMP of the first examples of cyclobutenyl-functionalized PLA and PCL macromonomers obtained from the ROP of the corresponding cyclic esters.

Over the past decade, the ROP of cyclic esters has been investigated using a large range of organocatalysts. ${ }^{12}$ Organocatalyzed ROP has the distinct advantage over stannous octoate-catalyzed ROP to require lower reaction temperatures that are more compatible with the cyclobutene thermal stability. ${ }^{5}$ Following the pioneering work of Hedrick and Waymouth on the ROP of lactide and lactones, ${ }^{13}$ organic bases such as guanidine (e.g., 1,5,7-triazabicyclo[4.4.0]dec-5-ene, TBD), amidine (e.g., 1,8- 
diazabicyclo[5.4.0]undec-7-ene, DBU), amine (4-( $N, N$-dimethylamino)pyridine, DMAP), thiourea (TU) derivatives, phosphines and phosphazenes (e.g., tert-butylimino-tris(dimethylamino)phosphorane, $t$-BuP B $_{1}$ and 2-tert-butylimino-2-diethylamino-1,3dimethylperhydro-1,2,3-diazaphosphorinane, BEMP) or $N$-heterocyclic carbenes (NHCs) have enabled the ROP of lactides, lactones (CL, $\delta$-valerolactone, $\beta$-butyrolactone) as well as of carbonates ((substituted) tri- and tetramethylene carbonates), reaching high polymerization rates and selectivities, and demonstrating tolerance to functional groups. As part of our ongoing efforts aimed at evaluating such organocatalysts in the ROP of cyclic esters, ${ }^{14}$ we focused the present study on TBD and DMAP. Both TBD and DMAP have successfully allowed the ROP of lactides and to a lesser extent of CL. ${ }^{13,15-18}$ TBD proved highly efficient in mediating the ROP of LA and CL. Indeed, associated ( $0.1 \%$ catalyst relative to monomer) to pyrenebutanol as the initiator (1\%) in dichloromethane (DCM), as many as 475 LA units were converted at room temperature within 1 min affording well-defined PLAs with controlled number-average molecular weights $\left(\bar{M}_{n}\right.$ up to 62600 g.mol $\left.{ }^{-1}\right)$ and low dispersity values (PDI < 1.2). ${ }^{15}$ TBD thus demonstrated a much higher reactivity toward the ROP of LA than its methyl-substituted analogue, 7-methyl-1,5,7triazabicyclo[4.4.0]dec-5-ene (MTBD) (495 LA units were converted in 30 min with $0.5 \%$ catalyst). ${ }^{15 a}$ Comparatively to LA, CL was polymerized more slowly by TBD with only 104 monomer units being consumed within $8 \mathrm{~h}$ at room temperature from a more concentrated catalyst solution ( $0.5 \%$ relative to monomer). ${ }^{15}$ Similarly, MeTBD was found less efficient compared to TBD in the ROP of CL with only $78 \mathrm{CL}$ units being consumed within $2 \mathrm{~h}$ by $5 \%$ catalyst relative to CL. A possible rationalization of the heightened reactivity of TBD relative to MeTBD is that it acts as a bifunctional catalyst activating both the monomer and the alcohol group of the initiator/propagating species. ${ }^{15 b, 19}$ DMAP was also found active in the ROP of LA and CL, in solution or in bulk. ${ }^{13,16,17}$ Associated with an alcohol (isopropyl alcohol, ethanol, benzyl alcohol) or with a ruthenium tris-hydroxylated initiator, namely $\left[\mathrm{Ru}\left(\mathrm{bpyPLA}_{2}\right)_{3}\right]\left[\mathrm{PF}_{6}\right]_{2}$, DMAP enabled the synthesis of linear and three-arm stars PLAs. Under mild operating conditions (bulk at $135^{\circ} \mathrm{C}$ or in DCM solution at $35^{\circ} \mathrm{C}$ ), using 0.1-4 equivalent(s) of amine relative to the initiating alcohol, polymers were recovered with $\bar{M}_{n}$ up to 57000 g.mol ${ }^{-1}$ and PDI < 1.26. A significant advantage of DMAP is its high selectivity during the propagation step. Also, as opposed to TBD, which was shown to catalyze transesterification reactions of the resulting aliphatic polyester if not quenched early enough before the completion of the polymerization, ${ }^{15}$ DMAP evidenced quite some resistance to undesirable interand/or intra-molecular transesterifications typically encountered in the ROP of cyclic esters (chain reshuffling and backbiting reactions, respectively). ${ }^{13,16,17,20,21}$

In this contribution, we report on the synthesis of well-defined cyclobutenyl end-capped PLA and PCL from the organocatalyzed ROP of LA and CL, respectively, mediated by TBD or DMAP catalyst in the presence of a mono- or di-hydroxylated cyclobutene derivative as initiator. Subsequent ROMP of these PLA and PCL macromonomers using $2^{\text {nd }}$ generation ruthenium-based Grubbs catalyst afforded well-defined poly(1,4-butadiene)- $g$-polyesters with controlled molecular weights and low dispersity.

\section{Experimental}

\section{General Characterization}

${ }^{1} \mathrm{H}$ Nuclear Magnetic Resonance (NMR) spectra were recorded on Bruker Avance 400 (200 MHz) and Bruker AC-400 (400 MHz) spectrometers. Chemical shifts are reported in ppm relative to the deuterated solvent resonances. Number-average degrees of polymerization $\left(\overline{D P_{n}}\right)$ were determined by ${ }^{1} \mathrm{H}$ NMR analysis, based on the comparison of the integrations of the cyclobutene alkene protons at $\delta=6.10-6.15 \mathrm{ppm}\left(2 \mathrm{H}\right.$, labeled (a) in Figure 1) against the methine signals of PLA at $\delta=5.10-5.20 \mathrm{ppm}\left(2 \times \mathrm{H} \times \overline{D P_{n}}\right.$, labeled (h) in Figure 1) (Table 1, Figure 1, Figures S3-S6 in Supporting Information). Similarly, $\overline{D P_{n, N M R}}$ values of PCL macromonomers were determined by the ratio of the integrations of the methylene group of PCL at 4.02-4.10 ppm (labeled (k) in Figure 5A) to the cyclobutene alkene protons at $\delta=6.10-6.15 \mathrm{ppm}$ (labeled (a) in Figure 5A) (Table 2, Figure 5A and Figures S10S12 in Supporting Information). CL conversions were determined from ${ }^{1} \mathrm{H}$ NMR spectra of the crude PCL sample, from the integration (Int) ratio $\operatorname{Int}_{\mathrm{PCL}}\left[\underline{\mathrm{Int}}_{\mathrm{PCL}}+\mathrm{Int}_{\mathrm{CL}}\right]$, using the $-\underline{\mathrm{CH}}_{2} \mathrm{OC}(\mathrm{O})$ methylene triplet $\left(\delta_{\mathrm{PCL}}=4.04 \mathrm{ppm}, \delta_{\mathrm{CL}}=4.19 \mathrm{ppm}\right)$. Numberaverage molecular weight $\left(\overline{M_{n}}\right)$ and dispersity (PDI $=\overline{M_{w}} / \overline{M_{n}}$ ) values were measured by Size Exclusion Chromatography (SEC) using tetrahydrofuran (THF) as an eluent, and carried out using a system equipped with a SpectraSYSTEM AS 1000 autosampler, with a Guard column (Polymer Laboratories, PL gel $5 \mu \mathrm{m}$ Guard column, 50 x $7.5 \mathrm{~mm}$ ) followed by two columns (Polymer Laboratories, 2 PL gel $5 \mu \mathrm{m}$ MIXED-D columns, 2 x 300 x 7.5) and with a SpectraSYSTEM RI-150 detector. The instrument operated at a flow rate of $1.0 \mathrm{~mL} \cdot \mathrm{min}^{-1}$ at $35{ }^{\circ} \mathrm{C}$ and was calibrated with narrow linear polystyrene (PS) standards with molecular weights ranging from $580 \mathrm{~g} \cdot \mathrm{mol}^{-1}$ to $483000 \mathrm{~g} \cdot \mathrm{mol}^{-1}$. All elution curves were calibrated with polystyrene standards. Matrix-Assisted Laser Desorption and Ionization Time Of Flight (MALDI-TOF) mass spectrometry analysis was performed on a Bruker Biflex III MALDI-TOF instrument equipped with a nitrogen laser operating at $337 \mathrm{~nm}$, a $2 \mathrm{GHz}$ sampling rate digitizer, pulsed ion extraction source and reflectron. The laser pulse width is $3 \mathrm{~ns}$ and maximum power is $200 \mathrm{~mJ}$. Spectra were recorded in the linear mode with an acceleration voltage of $19 \mathrm{kV}$ and a delay of $200 \mathrm{~ns} .100$ single shot acquisitions were summed to give the spectra and the data were analyzed using Bruker XTOF software. Samples were prepared by dissolving the matrix (trans-2-[3-(4-tert-butylphenyl)-2-methyl-2propenylidene]malononitrile, DCTB) in the solvent (dichloromethane, DCM, $30 \mathrm{mg} \cdot \mathrm{mL}^{-1}$ ) and mixing with the polymer (2 mg.mL ${ }^{-1}$ ) in the ratio 1:50 $(\mathrm{v} / \mathrm{v})$. An aliquot of this solution $(1 \mu \mathrm{L})$ was spotted directly onto a thin layer of sodium trifluoroacetate in acetone (concentration $19 \mathrm{mg} \cdot \mathrm{mL}^{-1}$ ) that had been deposited to act as a cationizing agent. 


\section{Reagents}

All chemicals were purchased from Aldrich unless otherwise noted. Acetic acid (98.0\%, Merck), chloroform $\left(\mathrm{CHCl}_{3},>99.8 \%\right), 1,8-$ diazabicyclo[5.4.0] undec-7-ene (DBU, 99\%), dichloroethane $\left(\mathrm{C}_{2} \mathrm{H}_{4} \mathrm{Cl}_{2},>99 \%\right.$, Merck Schuchard), dichloromethane (DCM, HPLC grade, Fisher Chemical), 4-( $N, N$-dimethylamino)pyridine (DMAP, > 99\%, Fluka), Grubbs' second generation catalyst (G2), $n$-hexane ( > 97.0\%), methanol (99\%), silica gel for chromatography $\left(\mathrm{SiO}_{2}, 0.035-0.070 \mathrm{~mm}, 60 \AA\right.$, Acros Organics), tetrahydrofuran (THF, > 99.8\%) and 1,5,7-triazabicyclo[4.4.0]dec-5-ene (TBD, 98\%) were used as received. $\varepsilon$-Caprolactone (CL, 99\%, Acros) and toluene $(99,9 \%)$ were distilled from $\mathrm{CaH}_{2} . \mathrm{L}$-lactide (LA, 98\%) was recrystallized in toluene three times prior to use. DCM and THF were dried over dry solvent stations GT S100. cis-Cyclobut-3-ene-1,2-dicarboxylic anhydride (1), ${ }^{22}$ cis-3,4bis(hydroxymethyl)cyclobutene (2), ${ }^{23}$ and cis-4-benzyloxymethyl-3-hydroxymethylcyclobutene (3) ${ }^{24}$ were synthesized according to literature procedures.

\section{General procedure for the preparation of cyclobutenyl-terminated PLA macromonomers via ROP}

A dry $10 \mathrm{~mL}$ Schlenk flask equipped with a stirring bar, a rubber septum, LA, catalyst, inimer and degassed anhydrous DCM were introduced into a glovebox. LA (1.00 g, $6.94 \mathrm{mmol})$ and catalyst (TBD or DMAP) were added into the Schlenk flask. The desired quantity of inimer (2 or 3) was dissolved in degassed anhydrous DCM (2.90 mL). This solution was added to the Schlenk flask (which was then capped with the rubber septum) and allowed to stir. When an homogeneous solution was obtained, the Schlenk flask was removed from the glovebox and immersed in an oil bath preset at $35^{\circ} \mathrm{C}$ to allow the polymerization to proceed (initial reaction time, $t=0$ ). The reaction mixture was stirred over the appropriate time. The polymerization was quenched by the addition of acetic acid solution in toluene $(0.2 \mathrm{~mL}, 16.5 \mathrm{mmol} / \mathrm{L})$. The resulting mixture was then concentrated to dryness under vacuum. The crude polymer was then dissolved in DCM $(2 \mathrm{~mL})$ and precipitated into cold methanol $(10 \mathrm{~mL})$, filtered and dried overnight under reduced pressure (typical isolated yield: 90-95\%). The recovered polymer was then analyzed by NMR, SEC, and MALDI-TOF mass spectrometry.

Cyclobutenyl-terminated PLA initiated from 3. White powder. $[\mathrm{LA}]_{0} /[3]_{0} /[\mathrm{DMAP}]_{0}=14 / 1 / 4$ (Table 1 , run 3$)$; $\overline{D P}{ }_{n, N M R}=18$; $\overline{M_{n, S E C}}=4100{\mathrm{~g} . \mathrm{mol}^{-1}}$; PDI = 1.15. ${ }^{1} \mathrm{H} \mathrm{NMR}\left(200 \mathrm{MHz}, \mathrm{CDCl}_{3}\right), \delta(\mathrm{ppm}): 7.35-7.30\left(\mathrm{~m}, 5 \mathrm{H}, \mathrm{C}_{6} H_{5}\right), 6.15-6.10(\mathrm{~m}, 2 \mathrm{H}, \mathrm{CH}=\mathrm{CH})$, 5.20-5.10 (q, $J=7 \mathrm{~Hz}, 48 \mathrm{H}, \mathrm{CH}-\mathrm{CH}_{3}$ of the PLA repeating unit), 4.50 (s, 2H, $\mathrm{CH}_{2}-\mathrm{C}_{6} \mathrm{H}_{5}$ ), 4.40-4.20 (m, $3 \mathrm{H}, \mathrm{CH}-\mathrm{CH}-\mathrm{O}-\mathrm{CO}$, $\left.\mathrm{C}(\mathrm{O}) \mathrm{CH}\left(\mathrm{CH}_{3}\right)-\mathrm{OH}\right), 3.55\left(\mathrm{~m}, 2 \mathrm{H}, \mathrm{CH}_{2}-\mathrm{O}-\mathrm{Bn}\right), 3.20\left(\mathrm{~m}, 2 \mathrm{H},=\mathrm{CH}-\mathrm{CH}-\mathrm{CH}_{2}\right), 1.55(\mathrm{~d}, \mathrm{~J}=7 \mathrm{~Hz}, 144 \mathrm{H}, \mathrm{CH}-\mathrm{CH}$ of the PLA repeating unit), 1.50 (m, 3H, $\left.\mathrm{CH}\left(\mathrm{CH}_{3}\right)-\mathrm{OH}\right)$ (Figure 1).

Cyclobutenyl-terminated PLA initiated from 2. White powder. $[\mathrm{LA}]_{0} /[2]_{0} /[\mathrm{DMAP}]_{0}=14 / 1 / 8($ Table 1, run 7$) ; \overline{D P}{ }_{n, N M R}=20$; $\overline{M_{n, S E C}}=4600{\mathrm{~g} . \mathrm{mol}^{-1}}$; PDI = 1.09. ${ }^{1} \mathrm{H} \mathrm{NMR}\left(200 \mathrm{MHz}, \mathrm{CDCl}_{3}\right), \delta(\mathrm{ppm}): 6.10(\mathrm{~s}, 2 \mathrm{H}, \mathrm{CH}=\mathrm{CH}), 5.20-5.10(\mathrm{q}, J=7 \mathrm{~Hz}, 40 \mathrm{H}, \mathrm{CH}-$ $\mathrm{CH}_{3}$ of the PLA repeating unit), 4.35-4.25 (m, $\left.6 \mathrm{H}, \mathrm{CH}-\mathrm{CH}_{2}-\mathrm{O}-\mathrm{C}(\mathrm{O}), \mathrm{C}(\mathrm{O}) \mathrm{CH}\left(\mathrm{CH}_{3}\right)-\mathrm{OH}\right), 3.25(\mathrm{~m}, 2 \mathrm{H},=\mathrm{CH}-\mathrm{CH}), 1.55(\mathrm{~d}, J=7 \mathrm{~Hz}$, $120 \mathrm{H}, \mathrm{CH}-\mathrm{CH}_{3}$ of the PLA repeating unit), $1.50\left(\mathrm{~m}, 6 \mathrm{H}, \mathrm{CH}\left(\mathrm{CH}_{3}\right)-\mathrm{OH}\right)$ (Figure $\mathrm{S} 5$ in Supporting Information).

\section{General procedure for the preparation of cyclobutenyl-terminated PCL macromonomers via ROP}

A dry 10 mL Schlenk flask equipped with a stirring bar, a rubber septum, CL, TBD, inimer and degassed anhydrous THF or toluene were introduced into a glovebox. The desired quantities of inimer ( 2 or $\mathbf{3}$ ) and TBD were added into the Schlenk flask and dissolved in degassed anhydrous THF or toluene $(4.4 \mathrm{~mL})$. The Schlenk flask was capped with a rubber septum and when an homogeneous solution was obtained, it was removed from the glovebox and immersed in an oil bath preset at $25^{\circ} \mathrm{C}$. CL $(1.00 \mathrm{~g}, 8.76 \mathrm{mmol})$ was added to the Schlenk flask via a syringe (initial reaction time, $t=0$ ) and the polymerization allowed to proceed. The reaction mixture was stirred over the appropriate time. The polymerization was quenched by the addition of acetic acid solution in toluene $(0.2 \mathrm{~mL}$, $16.5 \mathrm{mmol} / \mathrm{L}$ ). The resulting mixture was then concentrated to dryness under vacuum and the conversion determined by ${ }^{1} \mathrm{H} \mathrm{NMR}$ analysis of the residue in $\mathrm{CDCl}_{3}$. Finally, the crude polymer was dissolved in DCM $(2 \mathrm{~mL})$ and purified upon precipitation into cold methanol $(10 \mathrm{~mL})$, filtered and dried overnight under reduced pressure (typical isolated yield 90-95\%). The recovered polymer was then analyzed by NMR, SEC, and MALDI-TOF mass spectrometry.

Cyclobutenyl-terminated PCL initiated from 3. White powder. $[\mathrm{CL}]_{0} /[3]_{0} /[\mathrm{TBD}]_{0}=18 / 1 / 0.34$ (Table 2, run 4); conversion > 99\%; $\overline{D P_{n, N M R}}=16 ; \overline{M_{n, S E C}}=3900 \mathrm{~g} \cdot \mathrm{mol}^{-1} ; \mathrm{PDI}=1.10 .{ }^{1} \mathrm{H} \mathrm{NMR}\left(200 \mathrm{MHz}, \mathrm{CDCl}_{3}\right), \delta(\mathrm{ppm}): 7.35 \mathrm{ppm}\left(\mathrm{m}, 5 \mathrm{H}, \mathrm{C}_{6} H_{5}\right), 6.10(\mathrm{~s}, 2 \mathrm{H}$, $\mathrm{CH}=\mathrm{CH}), 4.50\left(\mathrm{~s}, 2 \mathrm{H}, \mathrm{O}-\mathrm{CH}_{2}-\mathrm{C}_{6} \mathrm{H}_{5}\right), 4.25\left(\mathrm{~m}, 2 \mathrm{H}, \mathrm{CH}-\mathrm{CH}_{2}-\mathrm{O}-\mathrm{C}(\mathrm{O})\right), 4.05\left(\mathrm{t}, \mathrm{J}=7 \mathrm{~Hz}, 32 \mathrm{H}, \mathrm{CH}_{2}-\mathrm{CH}_{2}-\mathrm{O}-\mathrm{C}(\mathrm{O})\right.$ of the PCL repeating unit), 3.70-3.55 (m, 4H, CH $\left.-\mathrm{O}-\mathrm{Bn}, \mathrm{CH}_{2}-\mathrm{OH}\right), 3.25(\mathrm{~m}, 2 \mathrm{H},=\mathrm{CH}-\mathrm{CH}), 2.30$ (t, $\mathrm{J}=7 \mathrm{~Hz}, 32 \mathrm{H}, \mathrm{O}-\mathrm{C}(\mathrm{O})-\mathrm{CH} \mathrm{H}_{2}-\mathrm{CH} \mathrm{CH}_{2}$ of the PCL repeating unit), 1.80-1.50 (m, $64 \mathrm{H}, \mathrm{C}(\mathrm{O})-\mathrm{CH}_{2}-\mathrm{CH}_{2}-\mathrm{CH}_{2}-\mathrm{CH}_{2}$ of the PCL repeating unit), 1.50-1.35 (m, 32H, $\mathrm{C}(\mathrm{O})-\left(\mathrm{CH}_{2}\right)_{2}-\mathrm{CH}_{2}$ of the PCL repeating unit) (Figure $5 \mathrm{~A})$.

Cyclobutenyl-terminated PCL initiated from 2. White powder. $[\mathrm{CL}]_{0} /[2]_{0} /[\mathrm{TBD}]_{0}=18 / 1 / 0.34$ (Table 2, run 1); conversion $>99 \%$; $\overline{D P_{n, N M R}}=19 ; \overline{M_{n, S E C}}=4400 \mathrm{~g} \cdot \mathrm{mol}^{-1} ; \mathrm{PDI}=1.08 .{ }^{1} \mathrm{H} \mathrm{NMR}\left(200 \mathrm{MHz}, \mathrm{CDCl}_{3}\right), \delta(\mathrm{ppm}): 6.10(\mathrm{~s}, 2 \mathrm{H}, \mathrm{CH}=\mathrm{CH}), 4.20(\mathrm{~m}, 4 \mathrm{H}$, $\left.\mathrm{CH}-\mathrm{CH}_{2}-\mathrm{O}-\mathrm{C}(\mathrm{O})\right), 4.05$ (t, $\mathrm{J}=7 \mathrm{~Hz}, 38 \mathrm{H}, \mathrm{CH}_{2}-\mathrm{O}-\mathrm{C}(\mathrm{O})$ of the PCL repeating unit), $3.65(\mathrm{t}, \mathrm{J}=6.5 \mathrm{~Hz}, 4 \mathrm{H}, \mathrm{CH}-\mathrm{OH}), 3.20(\mathrm{~m}, 2 \mathrm{H}$, $=\mathrm{CH}-\mathrm{CH}), 2.30\left(\mathrm{t}, \mathrm{J}=7.4 \mathrm{~Hz}, 38 \mathrm{H}, \mathrm{O}-\mathrm{C}(\mathrm{O})-\mathrm{CH}_{2}\right.$ of the PCL repeating unit), 1.80-1.50 (m, 76H, C(O)- $\mathrm{CH}_{2}-\mathrm{CH}_{2}-\mathrm{CH}_{2}-\mathrm{CH}_{2}$ of the PCL repeating unit), $1.50-1.35\left(\mathrm{~m}, 38 \mathrm{H}, \mathrm{C}(\mathrm{O})-\left(\mathrm{CH}_{2}\right)_{2}-\mathrm{CH}_{2}\right.$ of the PCL repeating unit) (Figure $\mathrm{S} 11$ in Supporting Information).

\section{General procedure for the preparation of graft copolymers via ROMP}

In a typical experiment, a dry Schlenk tube was charged with the desired quantity of macromonomer and a stir bar. The Schlenk flask 
was capped with a rubber septum, and cycled three times between vacuum and argon to remove oxygen. The desired quantity of degassed, anhydrous toluene or dichloroethane $\left([\mathrm{M}]_{0}=0.01-0.04 \mathrm{~mol} / \mathrm{L}\right)$ was added via a syringe under an argon atmosphere to dissolve the macromonomer. The Schlenk flask was immersed in an oil bath preset at $70^{\circ} \mathrm{C}$ and was stirred under argon for 10 min. A stock solution of catalyst $\mathbf{G 2}$ in degassed anhydrous toluene or dichloroethane $([\mathbf{G} 2]=47 \mathrm{mmol} / \mathrm{L})$ was prepared in a separate vial. The desired quantity of catalyst was injected into the macromonomer solution to initiate the polymerization. The reaction mixture was stirred over $3 \mathrm{~h}$. The polymerization was quenched by the addition of two drops of ethyl vinyl ether. The solvent was removed under reduced pressure for NMR and SEC measurements. The reaction mixture was then diluted in DCM and precipitated into 10 $\mathrm{mL}$ of stirred cold methanol. The crude $\mathrm{PBu}-\mathrm{g}$-PLA copolymers were dissolved in $\mathrm{CHCl}_{3}$ and passed through a short $\mathrm{SiO} 2$ column $(5$ $\mathrm{g}$ for a $0.2 \mathrm{~g} \mathrm{PBu}-\mathrm{g}$-PLA sample). The resulting polymer solution volumes were reduced, and white or slightly yellow copolymers were recovered by precipitating into hexane.

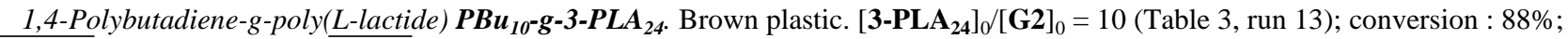
$\overline{M_{n, \text { theo }}}=36601 \mathrm{~g} \cdot \mathrm{mol}^{-1} ; \bar{M}_{n, S E C}=30500 \mathrm{~g} \cdot \mathrm{mol}^{-1} ; \mathrm{PDI}=1.10 .{ }^{1} \mathrm{H} \mathrm{NMR}\left(200 \mathrm{MHz}, \mathrm{CDCl}_{3}\right), \delta(\mathrm{ppm}): 5.10(\mathrm{q}, J=7.1 \mathrm{~Hz}, 212 \mathrm{H}$, $\mathrm{CH}_{-} \mathrm{CH}_{3}$ of the PLA repeating unit), $4.30\left(\mathrm{q}, J=7.2 \mathrm{~Hz}, 18 \mathrm{H}, \mathrm{C}(\mathrm{O}) \mathrm{CH}\left(\mathrm{CH}_{3}\right)-\mathrm{OH}\right), 1.52\left(\mathrm{~d}, J=7.2 \mathrm{~Hz}, 634 \mathrm{H}, \mathrm{CH}-\mathrm{CH}{ }_{3}\right.$ of the PLA repeating unit), $1.42\left(\mathrm{~d}, J=7.1 \mathrm{~Hz}, 52 \mathrm{H}, \mathrm{C}(\mathrm{O}) \mathrm{CH}\left(\mathrm{CH}_{3}\right)-\mathrm{OH}\right)$ (Figure $\mathrm{S} 22$ in Supporting Information).

1,4-Polybutadiene-g-poly(L-lactide) $\boldsymbol{P B} \boldsymbol{B u}_{10}-\boldsymbol{g}-\mathbf{- 2}-\boldsymbol{P L A} \boldsymbol{A}_{20}$. Brown plastic. [2-PLA 20 $]_{0} /[\mathbf{G 2}]_{0}=10$ (Table 3, run 17); conversion : $90 \% ; \overline{M_{n, t h e o}}=29901 \mathrm{~g} \cdot \mathrm{mol}^{-1} ; \overline{M_{n, S E C}}=20900 \mathrm{~g} \cdot \mathrm{mol}^{-1} ; \mathrm{PDI}=1.05 .{ }^{1} \mathrm{H} \mathrm{NMR}\left(200 \mathrm{MHz}, \mathrm{CDCl}_{3}\right), \delta(\mathrm{ppm}): 5.17(\mathrm{q}, J=7.1 \mathrm{~Hz}$, $180 \mathrm{H}, \mathrm{CH}-\mathrm{CH}_{3}$ of the PLA repeating unit), $4.36\left(\mathrm{q}, J=7.2 \mathrm{~Hz}, 18 \mathrm{H}, \mathrm{C}(\mathrm{O}) \mathrm{CH}\left(\mathrm{CH}_{3}\right)-\mathrm{OH}\right), 1.65-1.53(\mathrm{~d}, J=7.1 \mathrm{~Hz}, 540 \mathrm{H}, \mathrm{CH}-\mathrm{CH} 3 \mathrm{of}$ the PLA repeating unit), 1.53-1.46 (m, 54H, C(O) $\left.\mathrm{CH}\left(\mathrm{CH}_{3}\right)-\mathrm{OH}\right)$ (Figure $\mathrm{S} 23$ in Supporting Information).

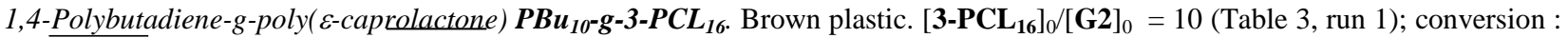

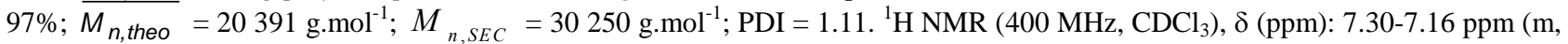
$\left.50 \mathrm{H}, \mathrm{C}_{6} H_{5}\right), 5.10-5.60(\mathrm{bs}, 20 \mathrm{H}, \mathrm{CH}=\mathrm{CH}), 4.06\left(\mathrm{t}, J=6.6 \mathrm{~Hz}, 320 \mathrm{H}, \mathrm{CH}_{2}-\mathrm{CH}_{2}-\mathrm{O}-\mathrm{C}(\mathrm{O})\right.$ of the PCL repeating unit), $3.65(\mathrm{t}, J=6.3$ $\left.\mathrm{Hz}, 20 \mathrm{H}, \mathrm{CH}_{2}-\mathrm{OH}\right), 2.31\left(\mathrm{t}, \mathrm{J}=7.4 \mathrm{~Hz}, 320 \mathrm{H}, \mathrm{O}-\mathrm{C}(\mathrm{O})-\mathrm{CH}_{2}-\mathrm{CH}_{2}\right.$ of the PCL repeating unit), 1.77-1.54 (m, 640H, C(O)-CH $-\mathrm{CH} 2^{-}$ $\mathrm{CH}_{2}-\mathrm{CH}_{2}$ of the PCL repeating unit), $1.48-1.28\left(\mathrm{~m}, 32 \mathrm{H}, \mathrm{C}(\mathrm{O})-\left(\mathrm{CH}_{2}\right)_{2}-\mathrm{CH}_{2}\right.$ of the PCL repeating unit) (Figure 5B).

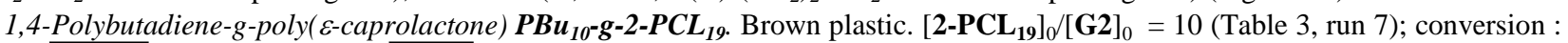
$95 \% ; \overline{M_{n, t h e o}}=22891 \mathrm{~g} . \mathrm{mol}^{-1} ; \overline{M_{n, S E C}}=22950 \mathrm{~g} \cdot \mathrm{mol}^{-1} ; \mathrm{PDI}=1.06 .{ }^{1} \mathrm{H} \mathrm{NMR}\left(200 \mathrm{MHz}, \mathrm{CDCl}_{3}\right), \delta(\mathrm{ppm}): 5.20-5.06 \mathrm{ppm}(\mathrm{bs}$, $20 \mathrm{H}, \mathrm{CH}=\mathrm{CH}$ ), 4.06 (t, $J=6.8 \mathrm{~Hz}, 380 \mathrm{H}, \mathrm{CH}_{2}-\mathrm{CH}_{2}-\mathrm{O}-\mathrm{C}(\mathrm{O})$ of the PCL repeating unit), 3.65 (t, $\left.J=6.8 \mathrm{~Hz}, 20 \mathrm{H}, \mathrm{CH}{ }_{2}-\mathrm{OH}\right), 2.31(\mathrm{t}, J$ $=7.3 \mathrm{~Hz}, 380 \mathrm{H}, \mathrm{O}-\mathrm{C}(\mathrm{O})-\mathrm{CH}_{2}-\mathrm{CH}_{2}$ of the PCL repeating unit), 1.77-1.53 (m, 760H, C(O)- $\mathrm{CH}_{2}-\mathrm{CH}_{2}-\mathrm{CH}_{2}-\mathrm{CH}_{2}$ of the PCL repeating unit), 1.50-1.29 (m, $380 \mathrm{H}, \mathrm{C}(\mathrm{O})-\left(\mathrm{CH}_{2}\right)_{2}-\mathrm{CH}_{2}$ of the PCL repeating unit) (Figure S24 in Supporting Information).

\section{Results and Discussion}

\section{Synthesis of $\alpha$-cyclobutenyl poly $(L$-lactide) (PLA) macromonomers}

PLA macromonomers end-capped by a cyclobutenyl group were synthesized by ring-opening polymerization (ROP) of $L$-lactide (LA) promoted by a catalytic system composed of an organocatalyst of the guanidine or amine type, namely 1,5,7triazabicyclo[4.4.0]dec-5-ene (TBD) or 4-(N,N-dimethylamino)pyridine (DMAP), in the presence of a di- or monohydroxylated derivative of cyclobutene, i. e., cis-3,4-bis(hydroxymethyl)cyclobutene (2) or cis-4-benzyloxymethyl-3-hydroxymethylcyclobut-1ene (3), used as initiator (Scheme 1). Representative results of these ROP experiments are summarized in Table 1.
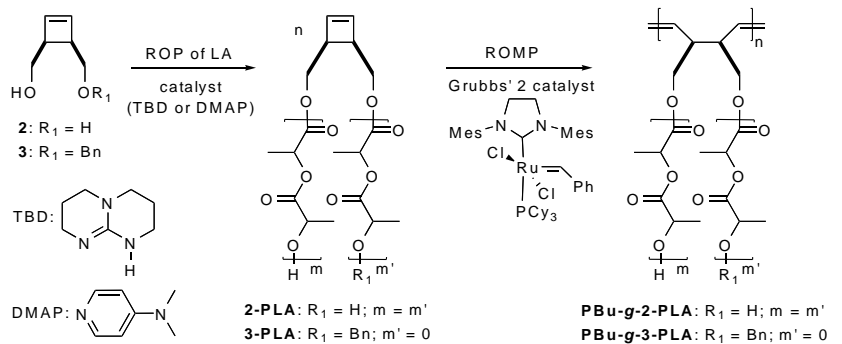

Scheme 1 Synthesis of PLA macromonomers from mono- or dihydroxyl inimers and their subsequent ROMP. 
Table 1 Characteristics of the 2-PLA and 3-PLA macromonomers synthesized upon ROP of LA mediated by TBD or DMAP catalysts and inimer 2 or 3 at $35^{\circ} \mathrm{C}$

\begin{tabular}{|c|c|c|c|c|c|c|c|c|}
\hline Run & Sample $^{a}$ & Catalyst & {$[\mathrm{LA}]_{0} /[\text { inimer }]_{0} /[\text { catalyst }]_{0}$} & $\begin{array}{l}\text { Reaction time } \\
\text { (h) }\end{array}$ & $\overline{D P_{n, N M R}}$ & $\begin{array}{c}\bar{M}_{n, N M R} d \\
\left(\mathrm{~g} \cdot \mathrm{mol}^{-1}\right)\end{array}$ & $\begin{array}{l}\bar{M}_{n, S E C}{ }^{e} \\
\left(\mathrm{~g} \cdot \mathrm{mol}^{-1}\right)\end{array}$ & $\mathrm{PDI}^{e}$ \\
\hline 1 & $3-\mathrm{PLA}_{24}$ & TBD & $14 / 1 / 0.5$ & 1 & 24 & 3660 & 4400 & 1.50 \\
\hline 2 & $3-\mathrm{PLA}_{24}$ & TBD & $14 / 1 / 0.5$ & 0.3 & 24 & 3660 & 4400 & 1.34 \\
\hline 3 & $3-\mathrm{PLA}_{18}$ & DMAP & $14 / 1 / 4$ & 24 & 18 & 2800 & 4100 & 1.15 \\
\hline 4 & $3-\mathrm{PLA}_{24}$ & DMAP & $14 / 1 / 4$ & 24 & 24 & 3660 & 4400 & 1.18 \\
\hline 5 & 3-PLA 41 & DMAP & $35 / 1 / 4$ & 48 & 41 & 6110 & 6600 & 1.16 \\
\hline 6 & $3-\mathrm{PLA}_{76}$ & DMAP & $70 / 1 / 4$ & 72 & 76 & 11150 & 7500 & 1.17 \\
\hline 7 & 2-PLA 20 & DMAP & $14 / 1 / 8$ & 22 & 20 & 2990 & 4600 & 1.09 \\
\hline 8 & $2-\mathrm{PLA}_{40}$ & DMAP & $34.5 / 1 / 8$ & 24 & 40 & 5870 & 9500 & 1.10 \\
\hline 9 & 2-PLA 77 & DMAP & $70 / 1 / 8$ & 24 & 77 & 11200 & 12200 & 1.14 \\
\hline
\end{tabular}

${ }^{a}$ In the sample name, the first number denotes the inimer and the last number in subscript refers to the number of LA repeating units determined by ${ }^{1} \mathrm{H}$ NMR. ${ }^{b}$ The reaction time was not necessarily optimized. ${ }^{c}$ Calculated from ${ }^{1} \mathrm{H}$ NMR spectra of precipitated macromonomer by comparing the peaks areas of the cyclobutene alkene protons at $\delta=6.10-6.15 \mathrm{ppm}$ and the methine proton of the PLA at $\delta=5.10-5.20 \mathrm{ppm} .{ }^{d}$ Determined by NMR analysis of precipitated macromonomer from $\overline{M_{n, N M R}}=\left(\overline{D P_{n, N M R}} \times \mathrm{M}_{\mathrm{LA}}\right)+\mathrm{M}_{\text {inimer }}$ with $\mathrm{M}_{\mathrm{LA}}=144 \mathrm{~g} \cdot \mathrm{mol}^{-1}, \mathrm{M}_{\text {inimer } 2}=114 \mathrm{~g} \cdot \mathrm{mol}^{-1}$ and M $\mathrm{M}_{\text {inimer } 3}=204$ g.mol ${ }^{-1} \cdot{ }^{e}$ Determined by SEC in tetrahydrofuran (THF) with RI detector, calibrated with linear polystyrene standards.

The polymerization of LA was first investigated from the TBD/3 catalytic system with a LA-to-initiator molar ratio of 14 in dichloromethane (DCM) at $35^{\circ} \mathrm{C}$ (Table 1, runs 1-2). The NMR spectra of the recovered PLAs showed the downfield shift of the signal of the methylene protons of the initiating group from $\delta=3.60-3.80$ ppm in 3 to $\delta=4.20-4.40$ ppm in 3-PLA 24 (Figure S1 in Supporting Information). SEC analysis of the crude products featured an unsymmetrical trace (Figure S2A in the Supporting Information) together with a rather broad dispersity (PDI = 1.50). A shorter reaction time allowed to decrease the PDI down to 1.34 while retaining a quantitative conversion (Table 1, run 2 vs 1). Nevertheless, SEC analysis of the crude product still displayed an unsymmetrical trace (Figure S2B in Supporting Information). These preliminary experiments suggested the occurrence of adverse side transesterification reactions - as quite often encountered in the TBD-catalyzed ROP of LA, ${ }^{15,20,21}$ and thus prompted the search for a better catalyst.

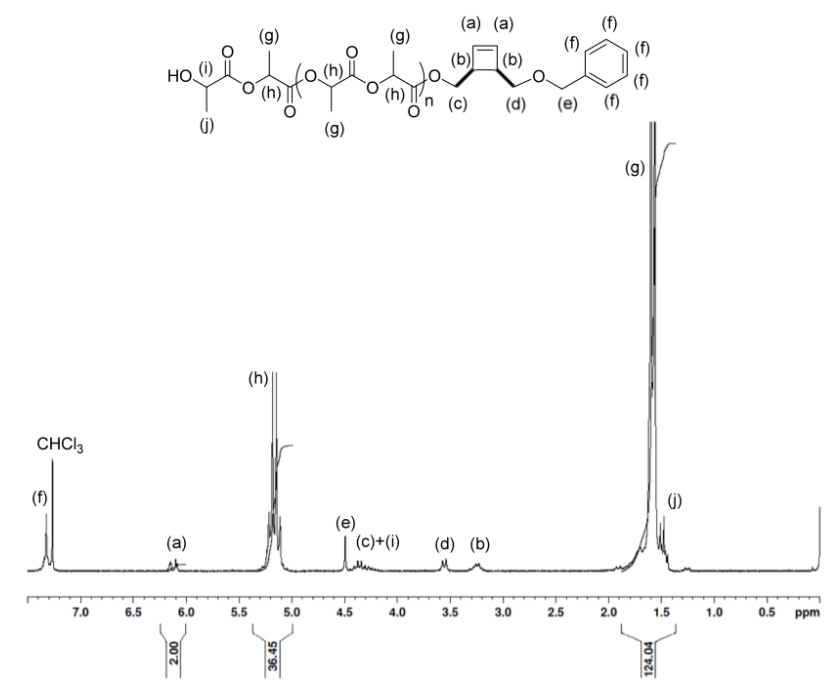

Fig. $1{ }^{1} \mathrm{H}$ NMR $\left(200 \mathrm{MHz}, \mathrm{CDCl}_{3}, 25{ }^{\circ} \mathrm{C}\right)$ spectrum of precipitated 3-PLA $\mathbf{A}_{18}$ issued from the ROP of LA in DCM at $35^{\circ} \mathrm{C}$ using inimer 3 as the initiator and DMAP as the catalyst with $[\mathrm{LA}]_{0} /[3]_{0}=14$ (Table 1 , run 3).

DMAP, a catalyst known to limit such transesterification reactions, ${ }^{12 b, 12 e, 13 a, 16}$ was then evaluated in the ROP of LA carried out in DCM at $35{ }^{\circ} \mathrm{C}$ (Table 1, runs 3-9). A series of cyclobutene-capped PLA macromonomers were thus synthesized from the DMAPpromoted ROP of LA, in the presence of cyclobutenes 2-3 featuring one or two hydroxyl initiating groups, respectively, with targeted number-average molecular weights $\left(\bar{M}_{n}\right)$ of 2000,5000 and 10000 g.mol ${ }^{-1}$. Number-average degrees of polymerization $\left(\overline{D P_{n}}\right)$ were determined by ${ }^{1} \mathrm{H}$ NMR analysis of the precipitated macromonomers, based on the comparison of the integrations of the cyclobutene alkene protons at $\delta=6.10-6.15 \mathrm{ppm}$ (labeled (a) in Figure 1) against the methine signals of the PLA at $\delta=5.10-5.20$ ppm (labeled (h) in Figure 1) (Table 1, Figure 1, Figures S3-S6 in Supporting Information). The experimental $D P_{n}$ values determined from NMR analysis increased with increasing $[\mathrm{LA}]_{0} /\left([2]_{0}\right.$ or $\left.[3]_{0}\right)$ ratio. SEC analyses indicated that the resulting 
macromonomers showed increasing $\overline{M_{n}}$ with increasing $[\mathrm{LA}]_{0} /\left([2]_{0}\right.$ or $\left.[3]_{0}\right)$ ratios, as evidenced by a shift of the SEC traces to the higher molar mass values, while retaining a narrow and unimodal elution peak with PDI in the range 1.16-1.18 (Figure 2 for 3-PLA macromonomers, Figure S7 in Supporting Information for 2-PLA macromonomers).

The end-group fidelity of the PLA macromonomers was confirmed by Matrix-Assisted Laser Desorption and Ionization Time Of Flight (MALDI-TOF) mass spectrometry analysis of a low molar mass sample of 3-PLA 18 macromonomer (Table 1, run 3) (Figure 3; Figure S8 in Supporting Information for 2-PLA $\mathbf{2 0}$ macromonomer). The spectrum displayed a major distribution spaced by $\mathrm{m} / \mathrm{z}=$ 144 , corresponding to the molar mass of the LA repeating unit (calculated value $=144.04 \mathrm{~g} \cdot \mathrm{mol}^{-1}$ ). The most intense signal detected at $\mathrm{m} / \mathrm{z}\left(\left[\mathrm{M}+\mathrm{Na}^{+}\right]\right)=2819.69$ is assignable to a sodium charged PLA chain with an even number of lactoyl repeating units $\left(\mathrm{C}(\mathrm{O}) \mathrm{CH}\left(\mathrm{CH}_{3}\right) \mathrm{O}\right)$ of 36, and with a 4-benzyloxymethyl-3-methylcyclobutene group and a hydroxyl group termini, which well-agrees with the calculated value (calculated isotopic mass for ${ }^{12} \mathrm{C}_{121}{ }^{1} \mathrm{H}_{160}{ }^{11} \mathrm{Na}^{16} \mathrm{O}_{74}=2819.86$ g.mol ${ }^{-1}$ ). Moreover, the other lower intensity series $\left(\mathrm{m} / \mathrm{z}\left(\left[\mathrm{M}+\mathrm{Na}^{+}\right]\right)=2747.67\right)$ corresponds to an analogous series depleted from one lactoyl fragment of the LA (calculated isotopic mass for 35 lactoyl repeating units: ${ }^{12} \mathrm{C}_{118}{ }^{1} \mathrm{H}_{156}{ }^{11} \mathrm{Na}^{16} \mathrm{O}_{72}=2747.84 \mathrm{~g} \cdot \mathrm{mol}^{-1}$ ), consistent with the occurrence of minor intermolecular transesterification side-reactions (backbiting), ${ }^{20}$ as hinted from the PDI of 1.18 measured by SEC.

\section{Synthesis of $\alpha$-cyclobutenyl poly( $\varepsilon$-caprolactone) (PCL) macromonomers}

PCL macromonomers end-terminated by a cyclobutenyl group were then similarly synthesized via ROP of $\varepsilon$-caprolactone (CL) initiated by inimer 2 or 3 with $[C L]_{0} /\left([2]_{0}\right.$ or $\left.[3]_{0}\right)$ feed ratios ranging from 14/1 to 70/1 (Scheme 2). The polymerization was performed at $25^{\circ} \mathrm{C}$ in THF or toluene, selecting TBD as the catalyst for its efficiency in promoting the ROP of CL and for its wider use relative to DMAP in reported procedures for the ROP of CL. ${ }^{15}$ Representative results of these ROP experiments are summarized in Table 2 .

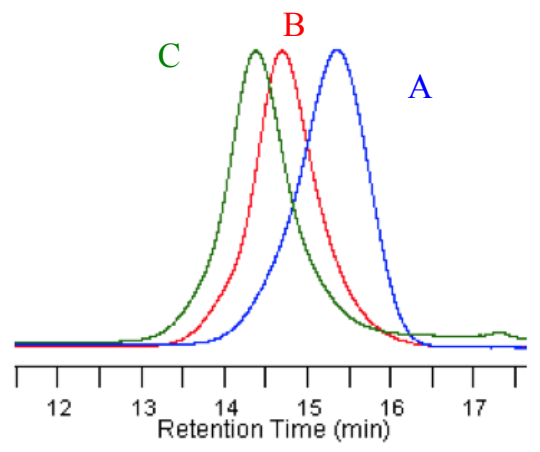

Fig. 2 SEC traces for (A) 3-PLA 18 (Table 1, run 3), (B) 3-PLA 4 (Table 1, run 5), and (C) 3-PLA 76 (Table 1, run 6).

Table 2 Characteristics of the 2-PCL and 3-PCL macromonomers synthesized upon ROP of CL mediated by TBD catalyst and inimer 2 or 3 at $25^{\circ} \mathrm{C}$

\begin{tabular}{|c|c|c|c|c|c|c|c|c|c|}
\hline Run & Sample $^{a}$ & {$[\mathrm{CL}]_{0} /[\text { inimer }]_{0} /[\mathrm{TBD}]_{0}$} & Solvent & $\begin{array}{l}\text { Reaction } \\
\text { time }^{b} \\
\text { (h) }\end{array}$ & $\begin{array}{c}\text { Conv. }{ }^{c} \\
(\%)\end{array}$ & $\begin{array}{c}\overline{D P_{n, N M R}} d \\
\left(\mathrm{~g} \cdot \mathrm{mol}^{-1}\right)\end{array}$ & $\begin{array}{l}\bar{M}_{n, N M R}{ }^{e} \\
\left(\mathrm{~g} \cdot \mathrm{mol}^{-1}\right)\end{array}$ & $\begin{array}{l}\bar{M}_{n, S E C} f \\
\left(\mathrm{~g} \cdot \mathrm{mol}^{-1}\right)\end{array}$ & $\mathrm{PDI}^{f}$ \\
\hline 1 & $2-\mathrm{PCL}_{19}$ & $18 / 1 / 0.34$ & THF & 4.5 & $>99$ & 19 & 2280 & 4400 & 1.08 \\
\hline 2 & 2-PCL 47 & $48 / 1 / 0.65$ & Toluene & 5 & $>99$ & 47 & 5470 & 8200 & 1.16 \\
\hline 3 & $2-\mathrm{PCL}_{81}$ & $96 / 1 / 0.65$ & Toluene & 5 & 81 & 81 & 9350 & 13700 & 1.18 \\
\hline 4 & 3- $\mathrm{PCL}_{16}$ & $18 / 1 / 0.34$ & THF & 4.5 & $>99$ & 16 & 2030 & 3900 & 1.10 \\
\hline 5 & $3-\mathrm{PCL}_{38}$ & $48 / 1 / 0.65$ & THF & 20 & 83 & 38 & 4300 & 5670 & 1.13 \\
\hline 6 & 3- $\mathrm{PCL}_{38}$ & $48 / 1 / 0.65$ & Toluene & 5 & 79 & 38 & 4340 & 5870 & 1.16 \\
\hline 7 & 3-PCL $\mathrm{PC}_{84}$ & $96 / 1 / 0.65$ & Toluene & 5 & 62 & 84 & 9780 & 10200 & 1.22 \\
\hline
\end{tabular}

${ }^{a}$ In the sample name, the first number denotes the inimer and the last number in subscript refers to the number of CL repeating units determined by ${ }^{1} \mathrm{H}$ NMR. ${ }^{b}$ The reaction time was not necessarily optimized. ${ }^{c}$ The CL monomer conversions were determined by comparing the peak areas of the methylene triplet of PCL at $\delta=4.02-4.10 \mathrm{ppm}$ and the methylene group of CL at $\delta=4.21 \mathrm{ppm}$ from ${ }^{1} \mathrm{H}$ NMR spectra of the crude mixture. ${ }^{d}$ Calculated from ${ }^{1} \mathrm{H}$ NMR spectra by comparing the peak areas of the cyclobutene alkene protons at $\delta=6.10-6.15 \mathrm{ppm}$ and the $-\mathrm{CH}_{2} \mathrm{CH} \mathrm{H}_{2} \mathrm{OC}(\mathrm{O})$ methylene triplet at $\delta=4.02-4.10 \mathrm{ppm} .{ }^{e}$ Determined by NMR analysis from $\overline{M_{n, N M R}}=\left(\overline{D P_{n, N M R}} \times \mathrm{M}_{\mathrm{CL}}\right)+\mathrm{M}_{\text {inimer }}$ with $\mathrm{M}_{\mathrm{CL}}=114 \mathrm{~g} \cdot \mathrm{mol}^{-1}, \mathrm{M}_{\mathrm{inimer} 2}=$ 114 g.mol ${ }^{-1}$ and $\mathrm{M}_{\text {inimer } 3}=204$ g.mol ${ }^{-1} .{ }^{f}$ Determined by SEC in tetrahydrofuran (THF) with RI detector, calibrated with linear polystyrene standards. 


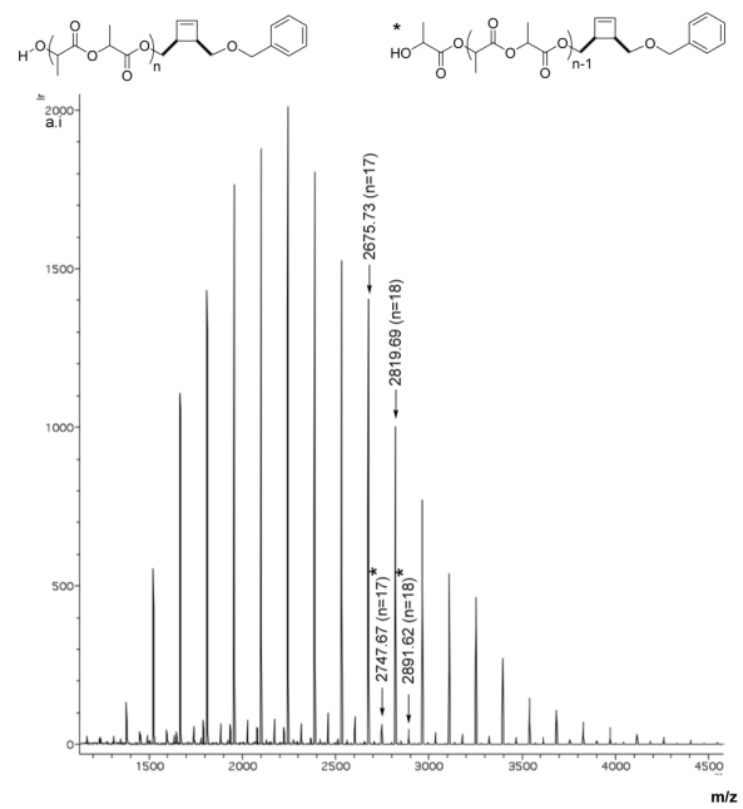

Fig. 3 MALDI-TOF mass spectrum (matrix: trans-2-[3-(4-tert-butylphenyl)-2-methyl-2-propenylidene]malononitrile (DCTB) + sodium trifluoroacetate (NaTFA)) of the cyclobutenyl-functionalized PLA synthesized by ROP using inimer $\mathbf{3}$ as the initiator and DMAP as the catalyst in DCM at $35^{\circ} \mathrm{C}$ with $[\mathrm{LA}]_{0} /[3]_{0}=14 / 1$ (Table 1 , run 3 ).
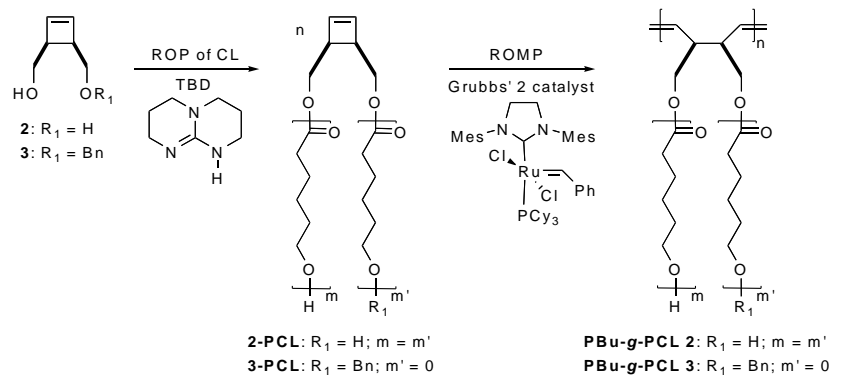

Scheme 2 Synthesis of PCL macromonomers from mono- or dihydroxyl inimers and their subsequent ROMP.

The ROP of CL in solution proceeded within a few hours (typically 5 hours) affording moderate-to-high CL conversions resulting in quite well-defined PCLs. Although the operating conditions were not strictly the same, the ROP of LA promoted by DMAP was found slower than that of CL mediated by TBD, whichever the inimer. For instance, TBD enabled the almost quantitative conversion of $48 \mathrm{CL}$ units in toluene within 5 hours thereby affording PCLs of molar mass up to $\overline{M_{n, S E C}}=13700$ g.mol ${ }^{-1}$ in comparison with DMAP wich required $48 \mathrm{~h}$ to afford a quantitative conversion of 41 LA units. All PCLs featured controlled molar mass values with molar mass values determined experimentally in good agreement with the calculated data. The SEC traces of the PCL macromonomers displayed a monomodal distribution with rather narrow dispersity values ranging from PDI $=1.08$ to 1.22 as depicted Figure 4 for 3-PCL macromonomers (Figure S9 in Supporting Information for 2-PCL macromonomers).

The resulting PCL macromonomers were further characterized by ${ }^{1} \mathrm{H}$ NMR spectroscopy and MALDI-TOF mass spectrometry. The end-capping of the PCL chains by cyclobutene was first demonstrated by ${ }^{1} \mathrm{H}$ NMR spectrum, which clearly showed the downfield shift of methylene protons of the initiating ROP group from $\delta=3.60-3.80 \mathrm{ppm}$ in $\mathbf{3}$ to $\delta=4.25 \mathrm{ppm}$ in $\mathbf{3}$-PCL macromonomers, as illustrated in Figure 5A (Figures S10-S12 in Supporting Information). $\overline{D P_{n}}$ were determined by ${ }^{1} \mathrm{H}$ NMR analysis, based on the comparison of the integrations of the cyclobutene alkene protons at $\delta=6.10-6.15$ ppm (labeled (a) in Figure 5A) against the $-\mathrm{CH}_{2} \mathrm{CH}_{2} \mathrm{OC}(\mathrm{O})$ methylene triplet of the PCL at $\delta=4.02-4.10 \mathrm{ppm}$ (labeled (k) in Figure 5A) (Table 2, Figure 5A, Figures S10-S12 in Supporting Information). The $\overline{D P_{n, N M R}}$ values of PCL macromonomers, determined by ${ }^{1} \mathrm{H}$ NMR, gave molar mass values in agreement with the ones predicted from the monomer feed ratios. Toluene was the favored solvent for the synthesis of higher molecular weight macromonomers, as it allows decreasing the reaction time while retaining a narrow dispersity (Table 2, runs 5-6). Quantitative chain-end functionalization of PCLs by the initiator was further confirmed by MALDI-TOF mass spectrometry analysis. The spectrum of a low molar mass sample of $\mathbf{3 - P C L} \mathbf{P}_{\mathbf{1 6}}$ macromonomer illustrated in Figure 6 revealed a unique distribution 
mode with a constant mass difference of 114 between each signal, corresponding to the molar mass of CL repeating unit (calculated value $=114.07 \mathrm{~g} \cdot \mathrm{mol}^{-1}$ ) (Figure S13 in Supporting Information for 2-PCL $\mathbf{1 9}$ macromonomer). The most intense peak at $\mathrm{m} / \mathrm{z}=$ 1824.06 corresponds to a polymer chain consisting of $14 \mathrm{CL}$ units, end-capped by 4-benzyloxymethyl-3-methylcyclobutene and hydroxyl groups, and a sodium atom responsible for ionization (calculated isotopic mass for ${ }^{12} \mathrm{C}_{97}{ }^{1} \mathrm{H}_{156}{ }^{11} \mathrm{Na}^{16} \mathrm{O}_{30}=1824.06$ g.mol ${ }^{-1}$ ).

(B)
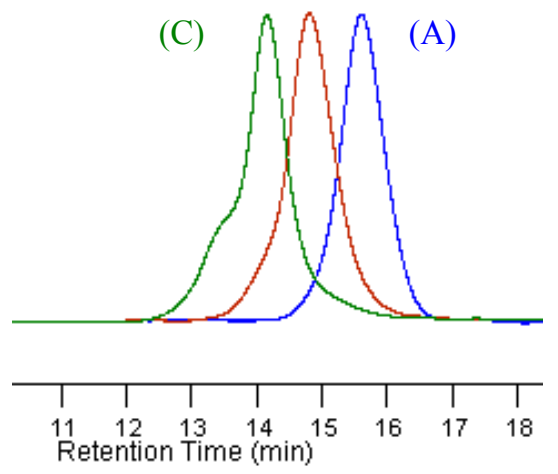

Fig. 4 SEC traces for (A) 3-PCL 16 (Table 2, run 4), (B) 3-PCL $\mathbf{3 8}$ (Table 2, run 6) and (C) 3-PCL $\mathbf{P C}_{\mathbf{8 4}}$ (Table 2, run 7).

(A)

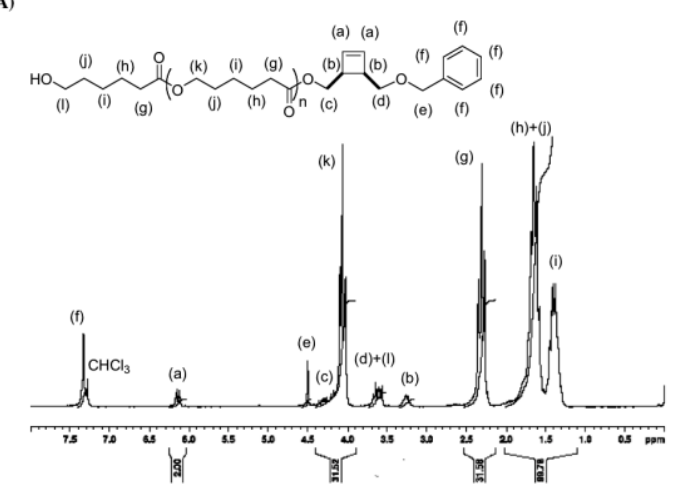

(B)

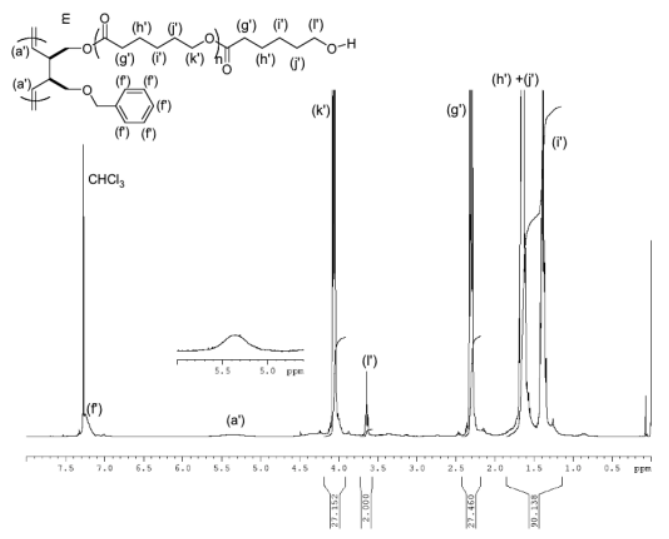

Fig. $5{ }^{1} \mathrm{H}$ NMR spectra $\left(200 \mathrm{MHz}, \mathrm{CDCl}_{3}, 25{ }^{\circ} \mathrm{C}\right)$ of precipitated (A) 3-PCL $\mathbf{L}_{\mathbf{1 6}}$ from the ROP of CL in THF at $25^{\circ} \mathrm{C}$ using inimer $\mathbf{3}$ as the initiator and TBD as the catalyst with $[\mathrm{CL}]_{0} /[\mathbf{3}]_{0}=18$ (Table 2, run 4), and (B) $\mathbf{P B u _ { 1 0 } - \mathbf { g } - \mathbf { 3 } - \mathbf { P C L }} \mathbf{L}_{\mathbf{1 6}}$ issued from the ROMP of $\mathbf{3 - P C \mathbf { L } _ { 1 6 }}$ in toluene at $70^{\circ} \mathrm{C}$ using $\mathbf{~ G 2}$ as the catalyst with $\left[\mathbf{3}-\mathbf{P C L}_{\mathbf{1 6}}\right] /[\mathbf{G} \mathbf{2}]=10$ for a reaction time of $3 \mathrm{~h}$ (Table 3 , run 1 ). 


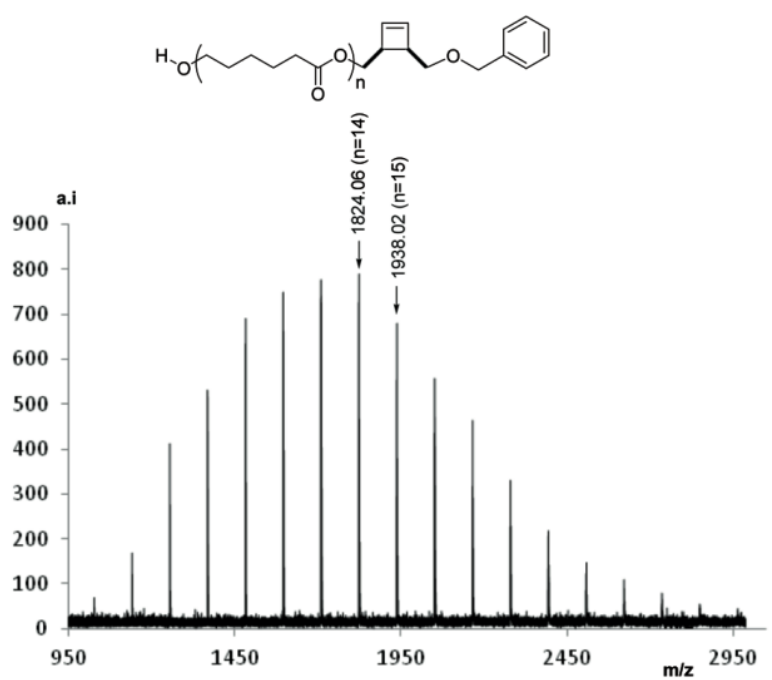

Fig. 6 MALDI-TOF mass spectrum (matrix: DCTB + NaTFA) of the cyclobutenyl-functionalized PCL synthesized by ROP using inimer 3 as the initiator and TBD as the catalyst in THF at $25^{\circ} \mathrm{C}$ with $[\mathrm{CL}]_{0} /[3]_{0}=18 / 1$ (Table 2 , run 4).

\section{ROMP of $\alpha$-cyclobutenyl PCL and PLA macromonomers}

PCL and PLA macromonomers with one (3-PCL, 3-PLA) and two (2-PCL, 2-PLA) arms of varying lengths were subjected to ROMP (Schemes $1 \& 2$ ) using $2^{\text {nd }}$ generation Grubbs' catalyst, which is one of the most active and thermally stable ROMP initiators $^{2 \mathrm{~h}, 3 \mathrm{a}-\mathrm{c}}$ especially for the ROMP of cyclobutene macromonomers ${ }^{4 \mathrm{a}, 5 \mathrm{a}, 7}$ and other sterically hindered macromonomers. ${ }^{3 \mathrm{a}, 10 \mathrm{a}}$

\section{ROMP of cyclobutenyl macromonomers bearing one PCL or PLA arm}

In order to have the macromonomer entirely polymerized, cyclobutene macromonomer with one PCL chain 3-PCL $\mathbf{L}_{16}$ with a $\overline{D P}$ of 16 and a low macromonomer-to-catalyst ratio of 10 was applied (Table 3, run 1). ROMP was carried out in toluene at $70^{\circ} \mathrm{C}$ with an olefin concentration of 0.01 mol.L ${ }^{-1}$. The final macromonomer conversion was measured by SEC. It was shown that ROMP of 3PCL $_{16}$ could afford well-defined brush copolymers with high overall macromonomer conversions (> 97\%) and a uniform size distribution, with a low PDI (1.11), similar to that of the macromonomer (PDI =1.10) (Figure 7A vs 7B), which demonstrated the living characteristics and high efficiency of "ROMP-able"-terminated macromonomers. The high conversion of 3-PCL $\mathbf{1 6}$ in ROMP was also revealed by ${ }^{1} \mathrm{H}$ NMR spectroscopic analysis. Indeed, in the spectrum of $\mathbf{P B u}_{\mathbf{1 0}} \mathbf{- g}-\mathbf{3}-\mathbf{P C L _ { 1 6 }}$ (Figure 5B), the total disappearance of the characteristic macromonomer olefinic protons resonance at $\delta=6.10 \mathrm{ppm}$ and the concomittant appearance of the 'ene' protons resonance of the $\mathrm{PBu}$ backbone at $\delta=5.10-5.60 \mathrm{ppm}$ confirms the quantitative consumption of the macromonomers, in good agreement with the SEC analysis. These results from SEC and NMR measurements indicated that a welldefined graft copolymer has been prepared. The $\overline{M_{n}}$ determination was complicated by ${ }^{1} \mathrm{H}$ NMR spectroscopy as the chain-ends are not observable. However, SEC measurements give access to the molecular weight values using a calibration with linear PS standards; these values were used for comparison only. 
Table 3 ROMP of PCL and PLA macromonomers using $2^{\text {nd }}$ generation Grubb's catalyst at $70^{\circ} \mathrm{C}$ during $3 \mathrm{~h}$

\begin{tabular}{|c|c|c|c|c|c|c|c|c|}
\hline Run & $\begin{array}{l}\text { Grafted } \\
\text { copolymer }\end{array}$ & {$[\mathrm{M}]_{0} /[]_{0}{ }^{a}$} & $\begin{array}{c}{[\mathrm{M}]_{0}} \\
\left(\mathrm{~mol} . \mathrm{L}^{-1}\right)\end{array}$ & Solvent & $\begin{array}{l}{\overline{M_{n, \text { theo }}}} b \\
\left(\mathrm{~g} \cdot \mathrm{mol}^{-1}\right)\end{array}$ & $\begin{array}{c}\text { Conv. }^{c} \\
\text { SEC (\%) }\end{array}$ & $\begin{array}{c}\bar{M}_{n, S E C} d \\
\left(\mathrm{~g} \cdot \mathrm{mol}^{-1}\right)\end{array}$ & $\mathrm{PDI}^{d}$ \\
\hline 1 & $\mathrm{PBu}_{10^{-}} g-3-\mathrm{PCL}_{16}$ & 10 & 0.01 & Toluene & 20391 & 97 & 30250 & 1.11 \\
\hline 2 & $\mathrm{PBu}_{50^{-}} g-3-\mathrm{PCL}_{16}$ & 50 & 0.01 & Toluene & 101591 & 85 & 84200 & 1.19 \\
\hline 3 & $\mathrm{PBu}_{50^{-}} g-3-\mathrm{PCL}_{16}$ & 50 & 0.04 & Toluene & 101591 & 95 & 97400 & 1.08 \\
\hline 4 & $\mathrm{PBu}_{100^{-}} g-3-\mathrm{PCL}_{16}$ & 100 & 0.04 & Toluene & 203091 & 65 & $--^{e}$ & $-e$ \\
\hline 5 & $\mathrm{PBu}_{10^{-}} g-3-\mathrm{PCL}_{38}$ & 10 & 0.01 & Toluene & 43131 & 79 & 43800 & 1.10 \\
\hline 6 & $\mathrm{PBu}_{10^{-}} g-3-\mathrm{PCL}_{84}$ & 10 & 0.01 & Toluene & 97891 & 80 & 80700 & 1.08 \\
\hline 7 & $\mathrm{PBu}_{10^{-}} g-2-\mathrm{PCL}_{19}$ & 10 & 0.01 & Toluene & 22891 & 95 & 22950 & 1.06 \\
\hline 8 & $\mathrm{PBu}_{50^{-}} g-2-\mathrm{PCL}_{19}$ & 50 & 0.04 & Toluene & 114091 & 95 & 79300 & 1.30 \\
\hline 9 & $\mathrm{PBu}_{100}-g-2-\mathrm{PCL}_{19}$ & 100 & 0.04 & Toluene & 228091 & 70 & $-e$ & $-^{e}$ \\
\hline 10 & $\mathrm{PBu}_{10^{-}} g-2-\mathrm{PCL}_{47}$ & 10 & 0.01 & Toluene & 54791 & 95 & 47100 & 1.11 \\
\hline 11 & $\mathrm{PBu}_{50^{-}} g-2-\mathrm{PCL}_{47}$ & 50 & 0.04 & Toluene & 273591 & 92 & 172200 & 1.30 \\
\hline 12 & $\mathrm{PBu}_{10^{-}} g-2-\mathrm{PCL}_{81}$ & 10 & 0.01 & Toluene & 93591 & 92 & 80100 & 1.05 \\
\hline 13 & $\mathrm{PBu}_{10^{-}} g-3-\mathrm{PLA}_{24}$ & 10 & 0.01 & $\mathrm{C}_{2} \mathrm{H}_{4} \mathrm{Cl}_{2}$ & 36601 & 88 & 30500 & 1.10 \\
\hline 14 & $\mathrm{PBu}_{50^{-}} g-3-\mathrm{PLA}_{24}$ & 50 & 0.04 & $\mathrm{C}_{2} \mathrm{H}_{4} \mathrm{Cl}_{2}$ & 183001 & 55 & 61650 & 1.09 \\
\hline 15 & $\mathrm{PBu}_{10}-g-3-\mathrm{PLA}_{41}$ & 10 & 0.01 & $\mathrm{C}_{2} \mathrm{H}_{4} \mathrm{Cl}_{2}$ & 61101 & 68 & 43600 & 1.10 \\
\hline 16 & $\mathrm{PBu}_{10}-g-3-\mathrm{PLA}_{76}$ & 10 & 0.01 & $\mathrm{C}_{2} \mathrm{H}_{4} \mathrm{Cl}_{2}$ & 111501 & 0 & $-^{e}$ & $-^{e}$ \\
\hline 17 & $\mathrm{PBu}_{10^{-}} g-2-\mathrm{PLA}_{20}$ & 10 & 0.01 & $\mathrm{C}_{2} \mathrm{H}_{4} \mathrm{Cl}_{2}$ & 29901 & 90 & 20900 & 1.05 \\
\hline 18 & $\mathrm{PBu}_{50^{-}}-2-2-\mathrm{PLA}_{20}$ & 50 & 0.04 & $\mathrm{C}_{2} \mathrm{H}_{4} \mathrm{Cl}_{2}$ & 149501 & 94 & 56350 & 1.17 \\
\hline 19 & $\mathrm{PBu}_{10}-g-2-\mathrm{PLA}_{40}$ & 10 & 0.01 & $\mathrm{C}_{2} \mathrm{H}_{4} \mathrm{Cl}_{2}$ & 58701 & 75 & 41000 & 1.08 \\
\hline 20 & $\mathrm{PBu}_{10^{-}} g-2-\mathrm{PLA}_{77}$ & 10 & 0.01 & $\mathrm{C}_{2} \mathrm{H}_{4} \mathrm{Cl}_{2}$ & 112001 & 32 & 60600 & 1.05 \\
\hline
\end{tabular}

${ }^{a}$ Macromonomer-to-catalyst molar ratio. ${ }^{b} \overline{M_{n, \text { theo }}}=\overline{M_{n, N M R}} *[\mathrm{M}]_{0} /[]_{0}+\mathrm{M}_{\text {extr. }}{ }^{c}$ Determined by comparing the peak areas of grafted copolymer and residual macromonomer from SEC measurement of the crude product. ${ }^{d}$ Determined by SEC in THF with RI detector, calibrated with linear polystyrene standards. ${ }^{e}$ Not determined.

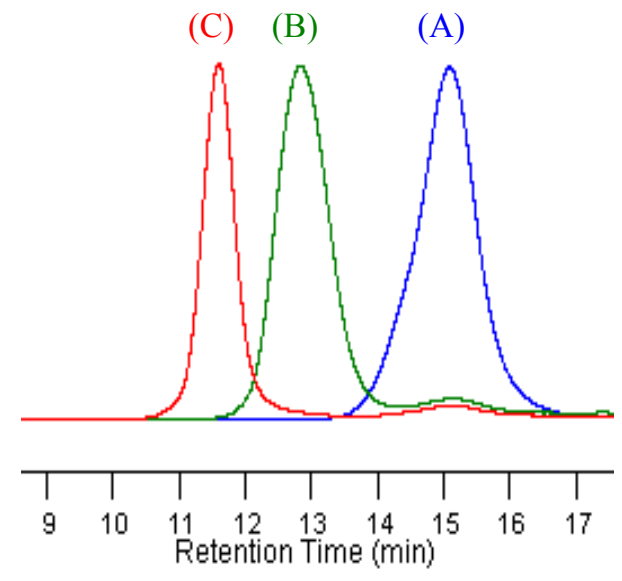

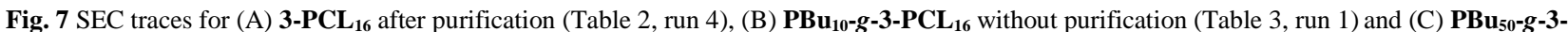
$\mathbf{P C L}_{16}$ without purification (Table 3 , run 3).

The influence of the macromonomer-to-catalyst ratio on the ROMP efficiency was then investigated. 3-PCL $\mathbf{L}_{\mathbf{1 6}}$ (Table 2, run 4) was first engaged in ROMP with a macromonomer-to-catalyst ratio of 50 (Table 3, runs 2-3). The ROMP proceeded almost to completion as ascertained by the SEC trace (Figure 7C), although a higher macromonomer concentration of $0.04 \mathrm{M}$ was necessary to achieve reasonable yield (Table 3, run 3 vs run 2, Figure S14A vs. S14B in Supporting Information). The line profile of the resulting $\mathbf{P B u}_{50}$ - $\mathbf{g}-3-\mathbf{P C L}_{16}$ is perfectly symmetrical together with a low dispersity (PDI = 1.08), supporting the controlled nature of the ROMP (Figure 7C). However, ROMP of 3-PCL $\mathbf{L}_{\mathbf{1 6}}$ (Table 2, run 4) with a macromonomer-to-catalyst ratio of 100 (Table 3, run 4) led to an incomplete conversion as observed by SEC (Figure S15B in Supporting Information). The extension of the reaction time to $24 \mathrm{~h}$ did not allow to increase the conversion (Figure S15C in Supporting Information). Steric hindrance from the growing polymacromonomer is probably the limiting factor of the polymerization. As the backbone length increases, the reactivity of the propagating center decreases, making more difficult the incorporation of new macromonomers. Feast et al. have demonstrated that the ROMP at high molar macromonomer-to-catalyst ratio ceases as a consequence of steric hindrance. ${ }^{25}$

ROMP performance of cyclobutene macromonomer with one PLA chain 3-PLA 24 (Table 1, run 4) with a $\overline{D P_{n}}$ of 24 was then studied. Polymerizations have been conducted in dichloroethane $\left(\mathrm{C}_{2} \mathrm{H}_{4} \mathrm{Cl}_{2}\right)$ as the PLA macromonomers are insoluble in toluene. The results show a decrease of reactivity compared to their PCL macromonomers analogs as the resulting copolymers issued from ROMP 
with macromonomer-to-catalyst ratios of 10 and 50 show a bimodal distribution of the SEC traces consistent with the presence of unreacted macromonomer (Table 3, runs 13-14, Figure S16 in Supporting Information). This difference in reactivity could be ascribed to a lack of solubility of the PLA macromonomers as it was necessary to heat the macromonomer solutions at $50^{\circ} \mathrm{C}$ for 5 min before adding the catalyst to ensure complete solubilization.

High molecular weight macromonomers with one PCL or PLA arm per cyclobutene have then been subjected to ROMP (Table 3, 5-6, 15-16). Conversions decreased noticeably with increasing $\overline{M_{n}}$ of the macromonomers even with a targeted low degree of polymerization $\left(\overline{D P_{n}}=10\right)$, as observed on the SEC traces (Figures S17, S18 and S19 in Supporting Information). The macromonomer chain length is a critical factor toward the conversion, probably due to the limiting effect of the macromonomer steric hindrance during the propagation step. ${ }^{5 \mathrm{a}, 10}$

\section{ROMP of cyclobutenyl macromonomers bearing two PCL or PLA arms}

ROMP of PCL macromonomers bearing two arms per cyclobutene was next studied. As determined by SEC analysis, high conversions (> 92\%) were obtained for macromonomer-to-catalyst ratios of 10 and 50 (Table 3, runs 7-8 and 10-12). Comparison of results obtained during ROMP of macromonomers having similar arm lengths (runs $10 v s .1$ and 11 vs. 3) suggests no influence of the side chain density. Nevertheless, the SEC trace of the crude $\mathbf{P B u}_{\mathbf{5 0}} \mathbf{- g}-\mathbf{- 2}-\mathbf{P C L}_{\mathbf{1 9}}$ (Table 3, run 8, Figure 8C) is unsymetrical with a small shoulder at higher molecular weights originating most likely from polymer chains which were formed by chain-coupling reactions, and a spreading toward lower molecular weights issued from backbiting ${ }^{26}$ revealing a loss of control of the polymerization as ascertained by the increase of the dispersity value $(\mathrm{PDI}=1.30)$.

(C) (B)

(A)

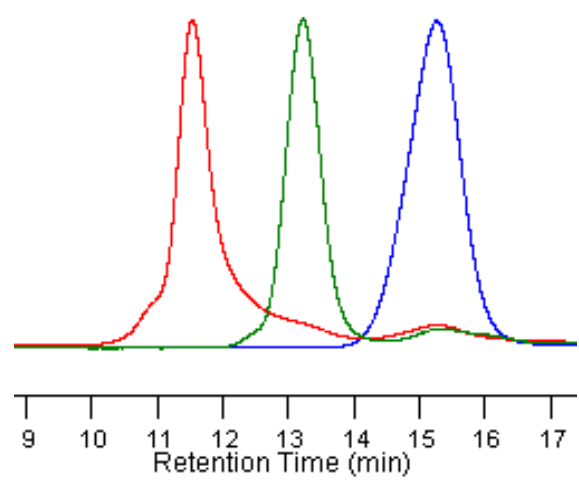

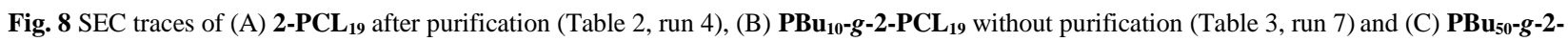
$\mathbf{P C L}_{19}$ without purification (Table 3, run 8).

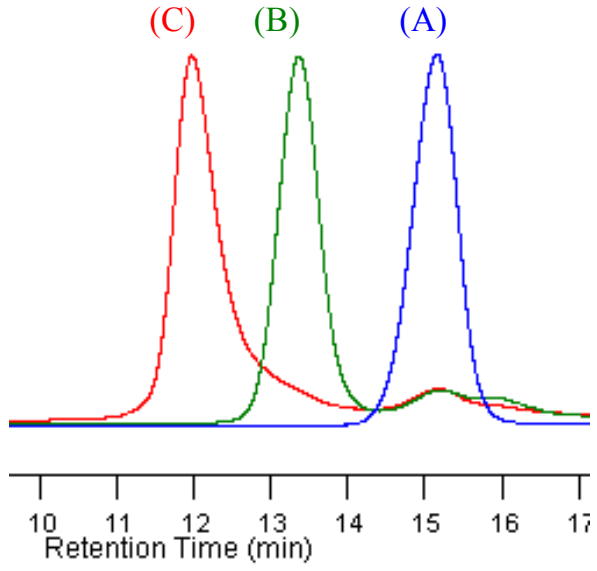

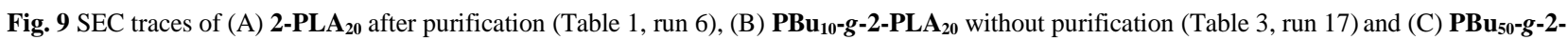
PLA $_{20}$ without purification (Table 3, run 18). 
For comparison, the reactivity of PLA macromonomers bearing two arms per cyclobutene toward ROMP was also investigated. As shown in Figure 9, conversion of 2-PLA 20 (Table 1, run 7) to brush polymer was very high (i.e., > 90\%) for a macromonomer-tocatalyst ratio of 10 (Table 3, run 17, Figure 9B). The well-defined structure of $\mathbf{P B u}_{\mathbf{1 0}} \mathbf{- g}-\mathbf{- 2}-\mathbf{P L A} \mathbf{2 0}$ was supported by SEC, with a monomodal molecular weight distribution and low dispersity (PDI < 1.05). Use of a macromonomer-to-catalyst ratio of 50 (Table 3 , run 18) has resulted in a similar conversion. Although the unpurified $\mathbf{P B u}_{\mathbf{5 0}}$-g-2-PLA $\mathbf{2 0}$ showed a monomodal distribution with low dispersity (1.17), increasing macromonomer-to-catalyst ratio entailed tailing of the elution profile in the SEC trace (Figure 9C) toward lower molecular weights, that can be ascribed to backbiting, confirming an ill-controlled polymerization. ${ }^{26}$ Crude copolymers were purified by passing the crude material through a silica column which allowed the removal of unreacted macromonomer as evidenced by the SEC profiles (Figure 10). As expected, ROMP of 2-PLA macromonomers with longer side chains (Table 3, runs 19-20) resulted in an incomplete conversion as shown by the multimodal SEC traces (Figures S20 and S21 in Supporting Information).

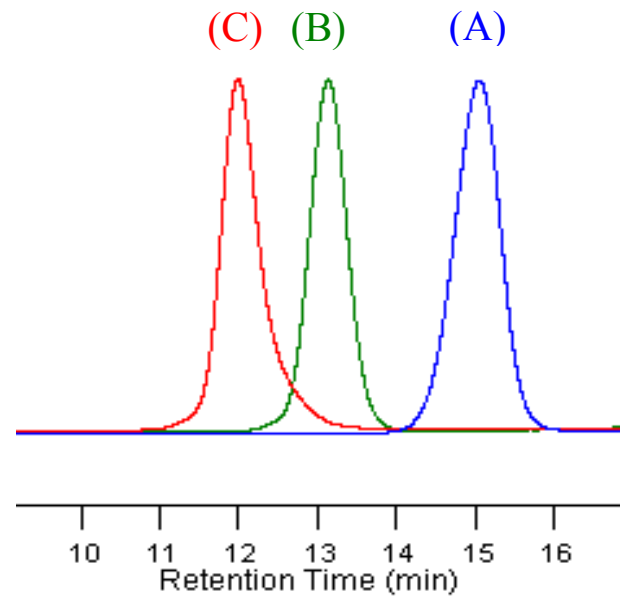

Fig. 10 SEC traces of (A) 2-PLA 20 (Table 1, run 6), (B) $\mathbf{P B u} \mathbf{u}_{\mathbf{1 0}}$ - -2-PLA $\mathbf{2 0}$ (Table 3, run 17) and (C) $\mathbf{P B \mathbf { u } _ { 5 0 } - \mathbf { g } - \mathbf { 2 } - \mathbf { P L A } \mathbf { 2 0 }}$ (Table 3, run 18) after purification.

\section{Conclusions}

Cyclobutenyl-terminated polyester macromonomers bearing one or two PCL or PLA arms have been successfully prepared by organocatalyzed ROP of CL or LA by DMAP or TBD combined with a cyclobutenyl alcohol acting as an initiator. This approach easily provides in high yields cyclobutenyl end-functionalized macromonomers with predictable molecular weights (up to 11000 g. $\mathrm{mol}^{-1}$ ) and narrow molecular weight distributions, and the length of the polyester block(s) can be easily tuned. Subsequent "grafting-through" by ROMP using Grubbs' second generation catalyst afforded polybutadiene brushes featuring pendant polyester (PLA or PCL) side-chains. This efficient ROP/ROMP two-step approach thus allowed the synthesis of well-defined poly(1,4butadiene)- $g$-polyesters copolymers. To the best of our knowledge, the products resulting from this strategy represent the first examples of poly(1,4-butadiene)-g-polyesters through the macromonomer route. These results pave the way to more complicated macromolecular architectures, e.g., by modification of the side-chain termini. Moreover, the hydrolytic (bio)degradation potential of the side chains (that can be used as sacrificial domains) of those bottlebrush copolymers makes them attractive candidates to be used for the preparation of complex hollowed nanostructures. ${ }^{27}$

\section{Acknowledgments}

We thank Emmanuelle Mebold, Jean-Claude Soutif, Patricia Gangnery, and Amélie Durand for MALDI-TOF mass spectrometry, high resolution mass spectrometry (HR-MS), and ${ }^{1} \mathrm{H}$ nuclear magnetic resonance (NMR) analyses.

\section{Notes and references}

1 (a) C. Tsitsilianis, Synthesis of Block and Graft Copolymers. In Controlled/Living Polymerizations; K. Matyjaszewski, A. H. E. Müller, Eds.; Wiley-VCH: Weinheim, 2009; pp 445-492. (b) R. Iha, K. L. Wooley, A. M. Nyström, D. J. Burke, M. J. Kade, C. J. Hawker, Chem. Rev. 2009, 109, 5620-5686. (c) S. S. Sheiko, B. S. Sumerlin, K. Matyjaszewski, Prog. Polym. Sci. 2008, 33, 759-785. (d) M. Zhang, A. H. E. Müller, J. Polym. Sci., Part A: Polym. Chem. 2005, 43, 3461-3481. (e) N. Hadjichristidis, M. Pitsikalis, H. Iatrou, S. Pispas, Macromol. Rapid Commun. 2003, 24, 979-1013.

2 Fo recent examples, see: (a) A. Li, J. Ma, G. R. Sun, Z. Li, S. H. Cho, C. Clark, K. L. Wooley, J. Polym. Sci., Part A: Polym. Chem. 2012, 50, 1681-1688. (b) A. Li, Z. Li, S. Y. Zhang, G. R. Sun, D. M. Policarpio, K. L. Wooley, ACS Macro Lett. 2012, 1, 241-245. (c) Y. K. Li, E. Themistou, J. Zou, B. P. Das, M. Tsianou, C. Cheng, ACS Macro Lett. 2012, 1, 52-56. (d) Y. K. Li, J. Zou, B. P. Das, M. Tsianou, C. Cheng, Macromolecules 2012, 45, 4623-4629. (e) A. O. Burts, Y. Li, A. V. Zhukhovitskiy, P. R. Patel, R. H. Grubbs, M. F. Ottaviani, N. J. Turro, J. A. 
Johnson, Macromolecules 2012, 45, 8310-8318. (f) A. M. Anderson-Wile, G. W. Coates, F. Auriemma, C. De Rosa, A. Silvestre, Macromolecules 2012, 45, 7863-7877. (g) J. G. Kim, G. W. Coates, Macromolecules 2012, 45, 7878-7883. (h) Q. Fu, J. M. Ren, G. G. Qiao, Polym. Chem. 2012, 3, 343-351. (i) F. Collette, R. Delatouche, C. Blanquart, F. Gueugnon, M. Gregoire, P. Bertrand, V. Heroguez, J. Polym. Sci., Part A: Polym. Chem. 2013, 51, 176-189. (j) F. Gueugnon, I. Denis, D. Pouliquen, F. Collette, R. Delatouche, V. Heroguez, M. Gregoire, P. Bertrand, C. Blanquart, Biomacromolecules 2013, 14, 2396-2402.

3 (a) I. Czelusniak, E. Khoshravi, A. M. Kenwright, C. W. G. Ansell, Macromolecules 2007, 40, 1444-1452. (b) G. Morandi, G. Mantovani, V. Montembault, D. M. Haddleton and L. Fontaine, New J. Chem. 2007, 31, 1826-1829. (c) M. R. Xie, J. Y. Dang, H. J. Han, W. Z. Wang, J. W. Liu, X. H. He, Y. Q. Zhang, Macromolecules 2008, 41, 9004-9010. (d) D. Le, V. Montembault, J.-C. Soutif, M. Rutnakornpituk, L. Fontaine, Macromolecules 2010, 43, 5611-5617.

4 (a) D. Le, G. Morandi, S. Legoupy, S. Pascual, V. Montembault and L. Fontaine, Eur. Polym. J. 2013, 49, 972-983. (b) G. Morandi, S. Pascual, V. Montembault, S. Legoupy, N. Delorme, L. Fontaine, Macromolecules 2009, 42, 6927-6931. (c) P. de Fremont, H. Clavier, V. Montembault, L. Fontaine, S. P. Nolan, J. Mol. Catal. A: Chem. 2008, 283, 108-113. (d) V. Lapinte, P. de Fremont, V. Montembault, L. Fontaine, Macromol. Chem. Phys. 2004, 205, 1238-1245. (e) V. Lapinte, L. Fontaine, V. Montembault, I. Campistron, D. Reyx, J. Mol. Catal. A: Chem. 2002, 190, $117-129$.

5 (a) G. Morandi, V. Montembault, S. Pascual, S. Legoupy and L. Fontaine, Macromolecules 2006, 39, 2732-2735. (b) S. Pioge, G. Morandi, S. Legoupy, V. Montembault, S. Pascual, L. Fontaine, Macromolecules 2008, 41, 9595-9601. (c) G. Morandi, S. Piogé, S. Pascual, V. Montembault, S. Legoupy and L. Fontaine, Mater. Sci. Eng. C 2009, 29, 367-371.

6 D. Le, V. Montembault, S. Pascual, S. Legoupy and L. Fontaine Macromolecules 2012, 45, 7758-7769.

7 D. Le, V. Montembault, S. Pascual, F. Collette, V. Heroguez, L. Fontaine, Polym. Chem. 2013, 4, 2168-2173.

8 (a) Z. Wu, D. R. Wheeler, R. H. Grubbs, J. Am. Chem. Soc. 1992, 114, 146-151. (b) Z. Wu, R. H. Grubbs, Macromolecules 1995, 28, 35023508. (c) R. B. Maughon, R. H. Grubbs, Macromolecules 1997, 30, 3459-3469. (d) M. G. Perrott, B. M. Novak, Macromolecules 1995, 28, 3492-3494. (e) M. G. Perrott, B. M. Novak, Macromolecules 1996, 29, 1817-1823. (f) J. C. Lee, K. A. Parker, N. S. Sampson, J. Am. Chem. Soc. 2006, 128, 4578-4579. (g) A. R. Song, K. A. Parker, N. S. Sampson, J. Am. Chem. Soc. 2009, 131, 3444-3445. (h) A. R. Song, K. A. Parker, N. S. Sampson, Org. Lett. 2010, 12, 3729-3731. (i) A. R. Song, J. C. Lee, K. A. Parker, N. S. Sampson, J. Am. Chem. Soc. 2010, 132, $10513-10520$. (j) K. Lee, T. L. Choi, Org. Lett. 2011, 13, 3908-3911.

9 (a) R. M. Rasal, A. V. Janorkar, D. E. Hirt, Prog. Polym Sci. 2010, 35, 338-356. (b) A. P. Gupta, V. Kumar, V. Eur. Polym. J. 2007, 43, 40534074. (c) S. Mecking, Angew. Chem., Int. Ed. 2004, 43, 1078-1085. (d) A.-C. Albertsson, I. K. Varma, Biomacromolecules $2003,4,1466-1486$. (e) Poly(Lactic Acid): Synthesis, Structures, Properties, Processing, and Applications; R. Auras, L.-T. Lim, S. E. M. Selke, H. Tsuji, Eds.; John Wiley \& Sons, Inc.: Hoboken, NJ, 2010.

10 (a) S. Jha, S. Dutta, N. B. Bowden, Macromolecules 2004, 37, 4365-4374. (b) Y. Xia, B. D. Olsen, J. A. Kornfield, R. H. Grubbs, J. Am. Chem. Soc. 2009, 131, 18525-18532.

11 (a) D. Yang, W. Huang, J. H. Yu, J. S. Jiang, L. Y. Zhang, M. R. Xie, Polymer 2010, 51, 5100-5106. (b) M. Xie, J. Dang, H. Han, W. Wang, J. Liu, X. He, Y. Zhang, Macromolecules 2008, 41, 9004-9010. (c) D. Mecerreyes, D. Dahan, P. Lecomte, P. Dubois, A. Demonceau, A. F. Noels, R. Jerome, J. Polym. Sci., Part A: Polym. Chem. 1999, 37, 2447-2455.

12 (a) M. Fevre, J. Pinaud, Y. Gnanou, J. Vignolle, D. Taton, Chem. Soc. Rev. 2013, 42, 2142-2172. (b) M. Fevre, J. Vignolle, Y. Gnanou, D. Taton, Polymer Science: A Comprehensive Reference 2012, 4, 67-115. (c) A. P. Dove, ACS Macro Lett. 2012, 1, 1409-1412. (d) M. K. Kiesewetter, E. J. Shin, J. L. Hedrick, M. R. Waymouth, Macromolecules 2010, 43, 2093-2107. (e) N. E. Kamber, W. Jeong, R. M. Waymouth, R. C. Pratt, B. G. G. Lohmeijer, J. L. Hedrick, Chem. Rev. 2007, 107, 5813-5840. (f) D. Bourissou, S. Moebs-Sanchez, B. Martin-Vaca, C. R. Chimie 2007, 10, 775-794. (g) O. Dechy-Cabaret, B. Martin-Vaca, D. Bourissou, Chem. Rev. 2004, 104, 6147-6176.

13 (a) F. Nederberg, E. F. Connor, M. Moeller, T. Glauser, J. L. Hedrick, Angew. Chem., Int. Ed. 2001, 40, 2712-2715. (b) F. Nederberg, E. F. Connor, T. Glausser, J. L. Hedrick, Chem. Commun. 2001, 2066-2067.

14 (a) S. M. Guillaume, J.-F. Carpentier, Catal. Sci. Techn. 2012, 2, 898-906; (b) N. Ajellal, J.-F. Carpentier, C. Guillaume, S. M. Guillaume, M. Helou, V. Poirier, Y. Sarazin, A. Trifonov, Dalton Trans. 2010, 39, 8363-8376; (c) M. Helou, O. Miserque, J.-M. Brusson, J.-F. Carpentier, S. M. Guillaume, Chem.-Eur. J. 2010, 16, 13805-13813; (d) P. Brignou, J.-F. Carpentier, S. M. Guillaume, Macromolecules 2011, 44, 5127-5135; (e) P. Brignou, M. Priebe Gil, O. Casagrande, J.-F. Carpentier, S. M. Guillaume, Macromolecules 2010, 43, 8007-8017; (f) M. Helou, J.-M. Brusson, J.-F. Carpentier, S. M. Guillaume, Polym. Chem. 2011, 2, 2789-2795; (g) C.-G. Jaffredo, J.-F. Carpentier, S. M. Guillaume, Macromol. Rapid Commun. 2012, 33, 1938-1944; (h) C.-G. Jaffredo, J.-F. Carpentier, S. M. Guillaume, Polym. Chem. 2013, 4, 3837-3850.

15 (a) B. G. G. Lohmeijer, R. C. Pratt, F. Leibfarth, J. W. Logan, D. A. Long, A. P. Dove, F. Nederberg, J. Choi, C. Wade, R. M. Waymouth, J. L. Hedrick, Macromolecules 2006, 39, 8574-8583; (b) R. C. Pratt, B. G. G. Lohmeijer, D. A. Long, R. M. Waymouth, J. L. Hedrick, J. Am. Chem. Soc. 2006, 128, 4556-4557.

16 M. Bouyahyi, M. P. F. Pepels, A. Heise, R. Duchateau, Macromolecules 2012, 45, 3356-3366.

17 (a) J. Kadota, D. E. Pavlovic, J.-P. Desvergne, B. Bibal, F. Peruch, A. Deffieux, Macromolecules 2010, 43, 8874-8879; (b) O. Coulembier, P. Dubois, Polym. Chem. 2012, 2, 1672-1680; (c) H. Feng, C.-M. Dong, J. Polym. Sci.; Part A: Polym. Chem. 2006, 44, 5353-5361.

18 G. Theryo, F. Jing, L. M. Pitet, M. A. Hillmyer, Macromolecules 2010, 43, 7394-7397.

19 (a) A. Chuma, H. W. Horn, W. C. Swope, R. C. Pratt, L. Zhang, B. G. G. Lohmeijer, C. G. Wade, R. M. Waymouth, J. L. Hedrick, J. E. Rice, J. Am. Chem. Soc. 2008, 130, 6749-6754; (b) L. Zhang, R. C. Pratt, F. Nederberg, H. W. Horn, J. E. Rice, R. M. Waymouth, C. G. Wade, J. L. Hedrick, Macromolecules 2010, 43, 1660-1664.

20 S. Penczek, R. Szymanski, A. Duda, J. Baran, Macromol. Symp. 2003, 201, 261-269.

21 A. Buchard, C. M. Bakewell, J. Weiner, C. K. Williams, Top. Organomet. Chem. 2012, 39, 175-224.

22 N. Gauvry, C. Comoy, C. Lescop, F. Huet, Synthesis 1999, 574-576.

23 L. Mevellec, F. Huet, Tetrahedron 1994, 50, 13145-13154.

24 L. Mevellec, M. Evers, F. Huet, Tetrahedron 1996, 52, 15103-15116.

25 W. J. Feast, V. C. Gibson, A. F. Johnson, E. Khosravi M. A. Mohsin, J. Mol. Catal. A: Chem. 1997, 115, $37-42$.

26 (a) C. W. Bielawski, R. H. Grubbs, Prog. Polym. Sci. 2007, 32, 1-29. (b) Handbook of Metathesis; R. H. Grubbs, Ed.; Wiley-VCH: Weinheim, Germany, 2003; Vol. 3.

27 (a) J. Rzayev, ACS Macro Lett. 2012, 1, 1146-1149. (b) M. Seo, M. A. Hillmyer, Science 2012, 336, 1422-1425. (c) D. Wu, F. Xu, B. Sun, R. Fu, H. He, K. Matyjaszewski, Chem. Rev. 2012, 112, 3959-4015. 